\title{
Health promotion interventions for African Americans delivered in U.S. barbershops and hair salons- a systematic review
}

Kelly N. B. Palmer ${ }^{1 *}$ (D) Patrick S. Rivers ${ }^{1}$, Forest L. Melton ${ }^{1}$, D. Jean McClelland ${ }^{2}$, Jennifer Hatcher ${ }^{3}$, David G. Marrero' ${ }^{1}$ Cynthia A. Thomson ${ }^{1}$ and David O. Garcia ${ }^{1}$

\begin{abstract}
Background: African American adults suffer disproportionately from obesity-related chronic diseases, particularly at younger ages. In order to close the gap in these health disparities, efforts to develop and test culturally appropriate interventions are critical.

Methods: A PRISMA-guided systematic review was conducted to identify and critically evaluate health promotion interventions for African Americans delivered in barbershops and hair salons. Subject headings and keywords used to search for synonyms of 'barbershops,' 'hair salons,' and 'African Americans' identified all relevant articles (from inception onwards) from six databases: Academic Search Ultimate, Cumulative Index of Nursing and Allied Health Literature (CINAHL), Embase, PsycINFO, PubMed, Web of Science (Science Citation Index and Social Sciences Citation Index). Experimental and quasi-experimental studies for adult ( $\geq 18$ years) African Americans delivered in barbershops and hair salons that evaluated interventions focused on risk reduction/management of obesity-related chronic disease: cardiovascular disease, cancer, and type 2 diabetes were included. Analyses were conducted in 2020.
\end{abstract}

Results: Fourteen studies met criteria for inclusion. Ten studies hosted interventions in a barbershop setting while four took place in hair salons. There was substantial variability among interventions and outcomes with cancer the most commonly studied disease state $(n=7 ; 50 \%)$, followed by hypertension $(n=5 ; 35.7 \%)$. Most reported outcomes were focused on behavior change $(n=10)$ with only four studies reporting clinical outcomes.

Conclusions: Health promotion interventions delivered in barbershops/hair salons show promise for meeting cancer screening recommendations and managing hypertension in African Americans. More studies are needed that focus on diabetes and obesity and utilize the hair salon as a site for intervention delivery.

Trial registration: PROSPERO CRD42020159050.

Keywords: African Americans, Chronic diseases, obesity, Cancer, Cardiovascular disease, Type 2 diabetes mellitus, Health promotion, Barbershops, Hair salons, Systematic review

\footnotetext{
* Correspondence: kpalmer1@arizona.edu

'Department of Health Promotion Sciences, Mel and Enid Zuckerman College of Public Health, University of Arizona, 1295 N Martin Avenue, Tucson, AZ 85721-0202, USA

Full list of author information is available at the end of the article
}

(C) The Author(s). 2021 Open Access This article is licensed under a Creative Commons Attribution 4.0 International License, which permits use, sharing, adaptation, distribution and reproduction in any medium or format, as long as you give appropriate credit to the original author(s) and the source, provide a link to the Creative Commons licence, and indicate if changes were made. The images or other third party material in this article are included in the article's Creative Commons licence, unless indicated otherwise in a credit line to the material. If material is not included in the article's Creative Commons licence and your intended use is not permitted by statutory regulation or exceeds the permitted use, you will need to obtain permission directly from the copyright holder. To view a copy of this licence, visit http://creativecommons.org/licenses/by/4.0/. The Creative Commons Public Domain Dedication waiver (http://creativecommons.org/publicdomain/zero/1.0/) applies to the data made available in this article, unless otherwise stated in a credit line to the data. 


\section{Background}

African Americans, the second largest minority group, account for $13.4 \%$ of the United States (U.S.) population [1]. African Americans are disproportionately burdened by obesity and related chronic diseases such as heart disease, cancer, and type 2 diabetes resulting in higher rates of morbidity and mortality than non-Hispanic whites (NHW) [2]. African Americans have the second highest prevalence for obesity and diabetes (46.8 and $12.7 \%$, respectively) of any racial/ethnic group [3]. African Americans have two times the risk of having stroke or dying from cardiovascular disease, and have $50 \%$ more risk of having hypertension than NHW [4]. African Americans are at higher risk of developing colorectal cancer and their mortality rates for multiple myeloma and stomach cancer are double that of NHW [5]. Moreover, prostate cancer mortality risk is two times as high for African American men as compared to NHW men; while African American women have higher risk of death from breast and cervical cancers than NHW [5]. Many social determinants of health (wage gaps, substandard education and healthcare, and unethical housing policies) are associated with health disparities among African Americans [6, 7]. Historically, African Americans have had mistrust in the medical and research community making them less likely to see a primary care doctor and participate in health promotion research [8-11]. Strategies to engage African Americans in health promotion programs must consider cultural appropriateness when designing and implementing effective health promotion interventions.

By working with community partners that deliver services to African Americans and trusted health care providers that are members of the African American community, interventionists can identify socioeconomic risk factors and barriers to healthcare utilization, facilitate coordination of care and resources, and implement evidence-based interventions to address health disparities. Engaging African Americans in health promotion interventions has been challenging likely in part due to a lack of consideration of the role culture plays in components such as intervention attendance and adherence. Typically, interventions are located in settings that have been perceived historically as inaccessible or excluding to African Americans further exacerbating health inequities. Toward this end, public health practitioners have turned to trusted community-based settings as sites for health promotion education and programming.

Health behavior researchers and programmers have utilized faith-based organizations to reach the African American community [12, 13]. The church has historically served as a source of refuge where members and the African American community at large can gather for non-religious purposes such as socialization and civic and political activities. As an integral part of the communities in which they reside, the church is often tasked with community outreach initiatives as well as economic development opportunities for local residents. Researchers and programmers can benefit from including core African American cultural constructs such as religiosity and social support/structure offered by the church in their interventions [14]. Furthermore, leveraging the social network by engaging leaders in the church that can reinforce participation or model the desired healthy behavior can be advantageous [15]. Integrating biblical texts and spiritual elements into the intervention increases program effectiveness [14]. For all the progress in reaching the African American community, there are limitations with church-placed and church-based interventions. Young African American adults and African American men are less likely than older African Americans and African American women to attend church services regularly [16]. Also, black churches have found themselves inundated with projects and competing interests making it difficult to prioritize health promotion programs [17].

Akin to the church, barbershops and hair salons are staples in the African American community. They impart important African American cultural constructs such as communalism and expressiveness [18]. Sociocultural influences of behavior can be explored and leveraged through the barbershop and hair salon. Barbershops and hair salons serve as sources of entrepreneurship; therefore, owners, barbers, and stylists alike are respected by members of the African American community. Because they are highly accessible, barbershops and hair salons have been involved in health promotion activities such as formative research, subject recruitment, and delivery/implementation of interventions [18-25]. Because African American men have traditionally been a difficult group to engage, barbershop health promotion has increased in popularity [26]. Oftentimes, African American men hang out for hours at the barbershop beyond their service visit. During this time one can network for a job, buy or sell products, advertise a business, watch movies or sports, discuss or get advice on personal and family affairs, and participate in other recreation (play board/video games, card, dominoes, etc.) [26].

Like their male counterparts, African American women maintain a high-level of engagement with the hair salon for many of the same reasons. Due to the unique and close relationship African American women have with their stylist, researchers can find opportunity in delivering interventions in hair salons and to a further extent by hair stylists [27-32]. Hair stylists are trusted by their clients and therefore serve as a confidante, a reliable source of information, and oftentimes as a close 
companion. This trust is in stark contrast to the mistrust of the medical system and research community common among African Americans. Because of this trust/mistrust, inaccessible quality healthcare, and lack of culturally appropriate interventions, African American woman are less likely to have a primary care provider [33]. However, it is more common for them to have a regular hair stylist illustrating the significance of routine hair care service [33]. Oftentimes hair care for African American women can require regular, lengthy visits to the salon thereby providing a captured audience suitable for health behavior interventions [34].

There is a paucity in the literature for systematic reviews that consider the role of the setting in engaging African Americans in health promotion. Among those, most have assessed cultural tailoring of evidence-based interventions (race concordance of interventionist, spirituality, etc.) [35-39]. A few have examined the role of churches, barbershops, and hair salons for recruitment of research participants into clinical trials [40, 41]. One synthesis of the literature explored barbershop and hair salon health promotion, but African Americans were not the primary population of interest [19]. Similarly, a 2015 qualitative systematic review described barber-led interventions targeted for African American men without inclusion of stylist-led interventions targeted for African American women [26]. This is the first systematic review of the effectiveness of barbershop and hair salon health promotion interventions for African Americans that elucidates the quality of evidence of these interventions. Characteristics of effective interventions addressing the leading obesity-related chronic disease (heart disease, cancer, and type 2 diabetes) health disparities for African Americans will be identified.

\section{Methods}

\section{Literature search}

This systematic review was conducted according to the guidelines set by the Preferred Reporting Items for Systematic Reviews and Meta-Analyses (PRISMA) statement [42]. The study was registered with the International Prospective Register of Systematic Reviews (PROSPERO) in 2020 (CRD42020159050). The detailed prespecified protocol has been previously published [43]. Seven databases (Academic Search Ultimate, Cumulative Index of Nursing and Allied Health Literature (CINA HL), Embase, PsychInfo, PubMed, Web of Science, and ProQuest Dissertations from inception to October 2019) were queried following comprehensive search strategies developed in consultation with a medical librarian (Additional file 1). Controlled vocabulary terms in databases (including $\mathrm{MeSH}$ and Emtree) and keywords were used in the search relevant to the target population (African Americans) and intervention component (delivery site- barbershops and/or hair salon) resulting in the following terms: "African American," "Black American," "African Ancestry," "barber," "barbering," "beautician," "beauty culture," "cosmetologist," "hair," "hairdresser," "hairstylist," "stylist," "beauty shop," "beauty salon," "hair salon," and "salon." The final search was conducted on October 08, 2019.

\section{Inclusion criteria/study selection}

Studies were included if they met the following inclusion criteria:

1) Adult African Americans were the target population for the intervention.

2) The intervention was delivered in a U.S. barbershop or hair salon.

3) The study evaluated an intervention aimed at reducing risk factors or improving health outcomes of obesity and/or related chronic conditions (i.e. cardiovascular disease, cancer, and type 2 diabetes).

Only interventional study designs were included. Studies were excluded if participants were children/adolescents (aged < 18 years), the intervention took place outside of the U.S., or if the article was published in a language other than English.

\section{Identification of eligible articles}

Figure 1 displays the screening and inclusion process depicted in a flow diagram. A search of the electronic databases yielded 1227 records by study author JM. After duplicates were removed, 973 records were uploaded to Covidence (Veritas Health Innovation, Melbourne Australia). Fifty-seven duplicates were removed, and 916 articles remained. Titles and abstracts were reviewed in triplicate by three of the study authors (KP, PR, and FM) resulting in 57 articles for full-text review. Study authors KP and PR independently reviewed the full text of each article against the inclusion/exclusion criteria. This resulted in 13 articles for inclusion in this review. One article reported on 2 studies, 2 articles are from the same study, but report different outcomes, and 2 articles are from the same study with one article reporting outcomes after extending the intervention $[21,29,30,44,45]$.

\section{Data extraction and quality assessment}

Data extraction was completed in duplicate by study authors KP and PR using a customized Research Electronic Data Capture (REDCap) database (Additional file 2) [46]. Data reports were reviewed for accuracy by FM. Data variables extracted from each article included: first author's last name, year of publication, article title, sample size, age range or mean age, gender, socioeconomic status of participants, geographic location, disease focus, 


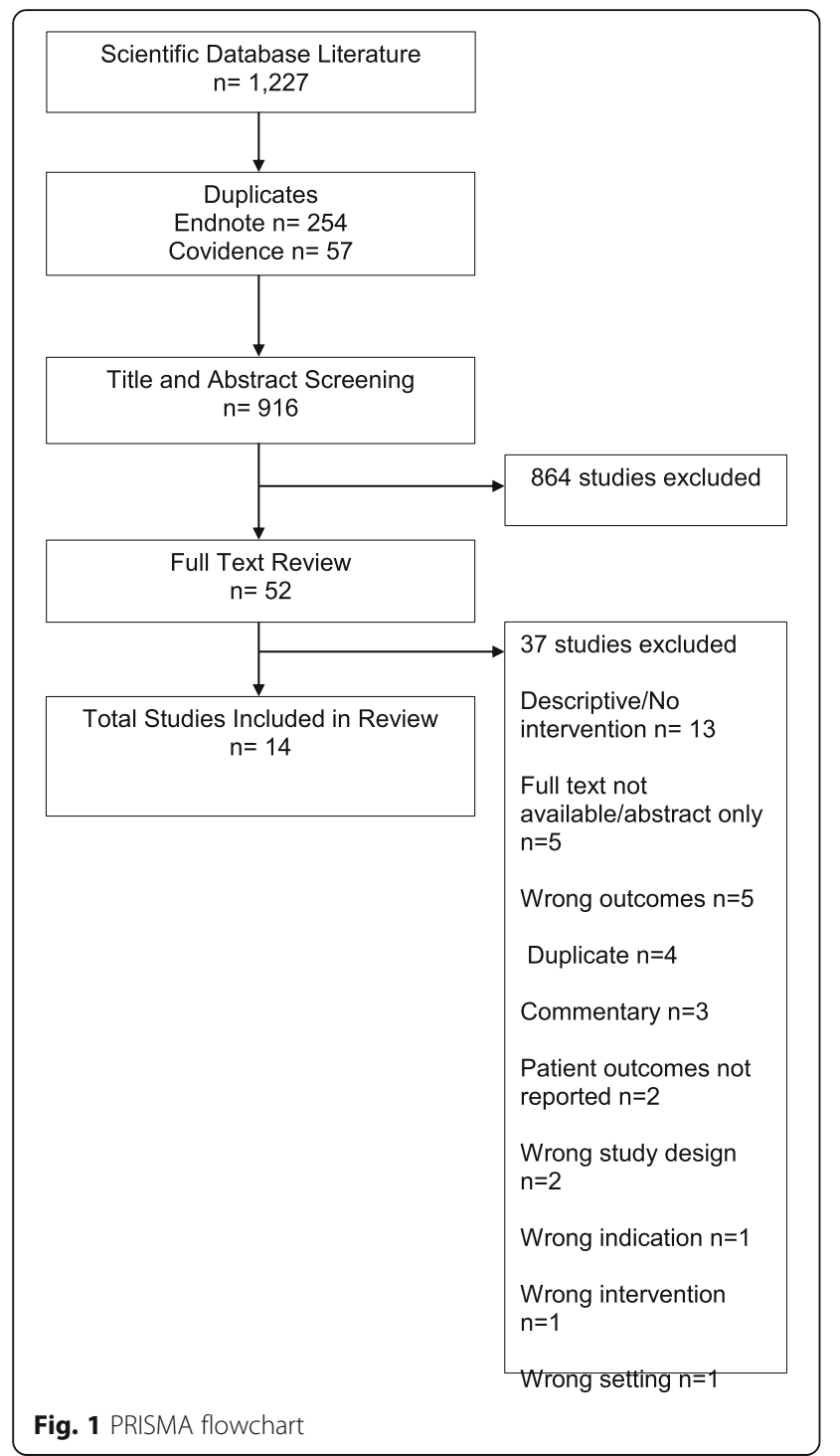

study design, study setting, intervention/control description, intervention duration, follow up time points, if a community-based participatory research approach was employed, interventionist, if culturally-sensitive strategies were implemented, if incentives were given, theoretical frameworks/models, barbershop/hair salon recruitment strategies, and study outcomes and results (noting significance). For studies where the barber/stylist was the interventionist, data on intervention training and strategies for intervention fidelity were also collected. Due to the heterogeneity of studies and outcomes, data were analyzed and synthesized for presentation narratively and in tables in 2020. Two authors (KP and PR) independently evaluated the quality of evidence using the Effective Public Health Practice Project Quality Assessment Tool (EPHPP) to increase inter-rater reliability and reduce risk of bias [47, 48]. Articles were given a global rating by each of the two reviewers of weak, moderate, or strong based on the six component ratings of selection bias, study design, confounders, blinding, data collection, and withdrawals/ dropouts. The two reviewers discussed global ratings for each article and a final decision of both reviewers was recorded in a REDCap database (Additional file 3).

\section{Results}

\section{Study characteristics}

Because one article reported outcomes for two studies [21], 14 studies are included in the final review. Characteristics of the 14 studies are presented in Table 1. Studies were published between 2007 and 2019. Seven studies were randomized control trials (RCTs) (six cluster RCTs and $1 \mathrm{RCT}$ ), four were pretest-posttest (three 2- group and one 1-group), two were nonrandomized feasibility studies, and one (1 group) posttest only study. Sample sizes varied widely from 20 to 1297 participants. Mean age of study participants ranged from 37 to 57.4 years, but ranges were wide with participants aged 18 to 88. Socioeconomic status (SES) was reported by all but two studies. Participants in three studies were reported as having only a high school education or less, lowincome, and/or mostly uninsured [20, 54, 55]. Studies were mostly conducted in large urban/metropolitan cities with only one in a rural area [20]. Seven interventions focused on outcomes related to cancer [27, 29, 50$53,55]$, five on cardiovascular disease (i.e. blood pressure) $[21,44,45,49]$, one on type 2 diabetes [30], and one on obesity [20]. Barbershops accounted for the majority of study settings $(n=9)[21,44,45,50-53,55,56]$, with four studies taking place in hair salons $[20,27,29$, 30]. Interventions taking place in barbershops targeted men $(n=9)[21,44,45,50-53,55,56]$ while those in hair salons targeted women $(n=4)[20,27,29,30]$.

\section{Interventions}

Table 2 summarizes characteristics of the interventions. All studies evaluated barbershop/hair salon-based health promotion interventions aimed at reducing risk factors for or improving health outcomes of obesity-related chronic conditions in African Americans. Interventions were extremely heterogenous in mode of delivery, duration, and content. Most interventions were delivered in-person, two were delivered via media (video/DVD) [50, 52], and one was delivered via phone calls [55]. Barbers and stylists served as the interventionists in most cases. In two studies, when not serving as the primary interventionist, barbers and stylists supported client engagement with the interventionist, a medical professional/pharmacist $[44,45]$. One study employed African American actors to portray barbers, barbershop clients, and doctors in a video-based intervention [52]. Two interventions were led by the researcher/research staff and 
Table 1 Study Characteristics

\begin{tabular}{|c|c|c|c|c|c|c|c|c|}
\hline $\begin{array}{l}\text { First } \\
\text { Author, } \\
\text { Year, } \\
\text { Ref }\end{array}$ & Title & $\begin{array}{l}\text { Sample } \\
\text { Size }\end{array}$ & $\begin{array}{l}\text { Mean Age/ } \\
\text { Age Range }\end{array}$ & SES & $\begin{array}{l}\text { Geographic } \\
\text { Location }\end{array}$ & $\begin{array}{l}\text { Study } \\
\text { Design }\end{array}$ & $\begin{array}{l}\text { Disease } \\
\text { State/Focus }\end{array}$ & Setting \\
\hline $\begin{array}{l}\text { Hess, } \\
2007 \text { [21] }\end{array}$ & $\begin{array}{l}\text { Barbershops as Hypertension } \\
\text { Detection, Referral, and Follow- } \\
\text { Up Centers for Black Men }\end{array}$ & $n=94$ & $40-60$ & $\begin{array}{l}\text { mostly insured or } \\
\text { have access to } \\
\text { public health care } \\
\text { system }\end{array}$ & Dallas, Texas & $\begin{array}{l}\text { Non- } \\
\text { Randomized } \\
\text { Feasibility }\end{array}$ & $\begin{array}{l}\text { Cardiovascular } \\
\text { Disease }\end{array}$ & Barbershop \\
\hline $\begin{array}{l}\text { Hess, } \\
2007 \text { [21] }\end{array}$ & $\begin{array}{l}\text { Barbershops as Hypertension } \\
\text { Detection, Referral, and Follow- } \\
\text { Up Centers for Black Men }\end{array}$ & $n=321$ & $40-60$ & $\begin{array}{l}\text { mostly insured or } \\
\text { have access to } \\
\text { public health care } \\
\text { system }\end{array}$ & Dallas, Texas & $\begin{array}{l}\text { Non- } \\
\text { Randomized } \\
\text { Feasibility }\end{array}$ & $\begin{array}{l}\text { Cardiovascular } \\
\text { Disease }\end{array}$ & Barbershop \\
\hline $\begin{array}{l}\text { Wilson, } \\
2008 \text { [27] }\end{array}$ & $\begin{array}{l}\text { Hair Salon Stylists as Breast } \\
\text { Cancer Prevention Lay Health } \\
\text { Advisors for African American } \\
\text { and Afro-Caribbean Women }\end{array}$ & $\begin{array}{l}n= \\
1185\end{array}$ & 38 & Not reported & $\begin{array}{l}\text { Brooklyn, } \\
\text { New York }\end{array}$ & $\begin{array}{l}\text { Cluster } \\
\text { Randomized } \\
\text { Control Trial }\end{array}$ & Cancer & Hair Salon \\
\hline $\begin{array}{l}\text { Holt, } \\
2010 \text { [49] }\end{array}$ & $\begin{array}{l}\text { Cancer Awareness in Alternative } \\
\text { Settings: Lessons Learned and } \\
\text { Evaluation of the Barbershop } \\
\text { Men's Health Project }\end{array}$ & $n=163$ & $45+$ & Not reported & $\begin{array}{l}\text { Birmingham, } \\
\text { Alabama }\end{array}$ & $\begin{array}{l}2 \text { group } \\
\text { Pretest- } \\
\text { Posttest }\end{array}$ & Cancer & Barbershop \\
\hline $\begin{array}{l}\text { Johnson, } \\
2010 \text { [20] }\end{array}$ & $\begin{array}{l}\text { Beauty Salon Health Intervention } \\
\text { Increases Fruit and Vegetable } \\
\text { Consumption in African- } \\
\text { American Women }\end{array}$ & $n=20$ & $18-70$ & $\begin{array}{l}>50 \%(11 / 20) \\
\text { High School } \\
\text { Diploma }\end{array}$ & $\begin{array}{l}\text { Rural South } \\
\text { Carolina }\end{array}$ & $\begin{array}{l}2 \text { group } \\
\text { Pretest- } \\
\text { Posttest }\end{array}$ & Obesity & Hair Salon \\
\hline $\begin{array}{l}\text { Luque, } \\
2011 \text { [50] }\end{array}$ & $\begin{array}{l}\text { Barbershop communications on } \\
\text { prostate cancer screening using } \\
\text { barber health advisers }\end{array}$ & $n=40$ & 53 & $\begin{array}{l}\text { mean } \\
\text { education }=14 \\
\text { years, mean } \\
\text { household } \\
\text { income }<\$ 70 \mathrm{k} \text {, } \\
78 \% \text { privately } \\
\text { insured }\end{array}$ & $\begin{array}{l}\text { Tampa, } \\
\text { Florida }\end{array}$ & $\begin{array}{l}1 \text { group } \\
\text { Posttest only }\end{array}$ & Cancer & Barbershop \\
\hline $\begin{array}{l}\text { Sadler, } \\
2011 \text { [29] }\end{array}$ & $\begin{array}{l}\text { A Cluster Randomized } \\
\text { Controlled Trial to Increase } \\
\text { Breast Cancer Screening Among } \\
\text { African American Women: The } \\
\text { Black Cosmetologists Promoting } \\
\text { Health Program }\end{array}$ & $n=984$ & $\begin{array}{l}40.6 \\
20-88\end{array}$ & $\begin{array}{l}\text { mostly college } \\
\text { educated (52\% } \\
\text { some college, } \\
34 \% \text { complete } \\
\text { college) }\end{array}$ & $\begin{array}{l}\text { San Diego, } \\
\text { California }\end{array}$ & $\begin{array}{l}\text { Cluster } \\
\text { Randomized } \\
\text { Control Trial }\end{array}$ & Cancer & Hair Salon \\
\hline $\begin{array}{l}\text { Victor, } \\
2011 \text { [27] }\end{array}$ & $\begin{array}{l}\text { Effectiveness of a Barber-Based } \\
\text { Intervention for Improving } \\
\text { Hypertension Control in Black } \\
\text { Men }\end{array}$ & $\begin{array}{l}n= \\
1297\end{array}$ & $\begin{array}{l}\text { Intervention: } \\
49.5 \\
\text { Control: } 51.2\end{array}$ & $\begin{array}{l}85 \% \text { middle } \\
\text { income and } \\
\text { insured }\end{array}$ & Dallas, Texas & $\begin{array}{l}\text { Cluster } \\
\text { Randomized } \\
\text { Control Trial }\end{array}$ & $\begin{array}{l}\text { Cardiovascular } \\
\text { Disease }\end{array}$ & Barbershop \\
\hline $\begin{array}{l}\text { Odedina, } \\
2014 \text { [51] }\end{array}$ & $\begin{array}{l}\text { Development and assessment of } \\
\text { an evidence-based prostate can- } \\
\text { cer intervention programme for } \\
\text { black men: the W.O.R.D. on pros- } \\
\text { tate cancer video }\end{array}$ & $n=142$ & $50-59$ & $\begin{array}{l}>50 \%:<\$ 20 \text { k, H.S. } \\
\text { diploma, had } \\
\text { insurance, had } \\
\text { PCP }\end{array}$ & Florida & $\begin{array}{l}1 \text { group } \\
\text { Pretest- } \\
\text { Posttest }\end{array}$ & Cancer & Barbershop \\
\hline $\begin{array}{l}\text { Sadler, } \\
2014 \text { [30] }\end{array}$ & $\begin{array}{l}\text { Lessons learned from The Black } \\
\text { Cosmetologists Promoting } \\
\text { Health Program: A randomized } \\
\text { controlled trial testing a } \\
\text { diabetes education program }\end{array}$ & $n=984$ & $\begin{array}{l}40.6 \\
20-88\end{array}$ & $\begin{array}{l}\text { mostly college } \\
\text { educated ( } 52 \% \\
\text { some college, } \\
34 \% \text { complete } \\
\text { college) }\end{array}$ & $\begin{array}{l}\text { San Diego, } \\
\text { California }\end{array}$ & $\begin{array}{l}\text { Cluster } \\
\text { Randomized } \\
\text { Control Trial }\end{array}$ & $\begin{array}{l}\text { Type } 2 \\
\text { Diabetes }\end{array}$ & Hair Salon \\
\hline $\begin{array}{l}\text { Frencher, } \\
2016 \text { [52] }\end{array}$ & $\begin{array}{l}\text { PEP Talk: Prostate Education } \\
\text { Program, Cutting Through the } \\
\text { Uncertainty of Prostate Cancer } \\
\text { for Black Men Using Decision } \\
\text { Support Instruments in } \\
\text { Barbershops }\end{array}$ & $n=120$ & $40+$ & $\begin{array}{l}\text { majority } \\
\text { income }<\$ 24 \mathrm{k} ; \\
\text { uninsured, college } \\
\text { or more }\end{array}$ & $\begin{array}{l}\text { South Los } \\
\text { Angeles, } \\
\text { California }\end{array}$ & $\begin{array}{l}2 \text { group } \\
\text { Pretest- } \\
\text { Posttest }\end{array}$ & Cancer & Barbershop \\
\hline $\begin{array}{l}\text { Cole, } \\
2017 \text { [53] }\end{array}$ & $\begin{array}{l}\text { Community-Based, Preclinical } \\
\text { Patient Navigation for Colorectal } \\
\text { Cancer Screening Among Older } \\
\text { Black Men Recruited From } \\
\text { Barbershops: The MISTER B Trial }\end{array}$ & $n=731$ & $\begin{array}{l}57.4 \\
50+\end{array}$ & $\begin{array}{l}\text { mean annual } \\
\text { income }=\$ 16,726 \\
1 / 3<\text { High School } \\
\text { diploma, } \sim 50 \% \\
\text { unemployed }\end{array}$ & $\begin{array}{l}\text { New York, } \\
\text { New York }\end{array}$ & $\begin{array}{l}\text { Randomized } \\
\text { Control Trial }\end{array}$ & Cancer & Barbershop \\
\hline Victor, & A Cluster-Randomized Trial of & $n=319$ & Intervention: & mostly college & Los Angeles, & Cluster & Cardiovascular & Barbershop \\
\hline
\end{tabular}


Table 1 Study Characteristics (Continued)

\begin{tabular}{|c|c|c|c|c|c|c|c|c|}
\hline $\begin{array}{l}\text { First } \\
\text { Author, } \\
\text { Year, } \\
\text { Ref }\end{array}$ & Title & $\begin{array}{l}\text { Sample } \\
\text { Size }\end{array}$ & $\begin{array}{l}\text { Mean Age/ } \\
\text { Age Range }\end{array}$ & SES & $\begin{array}{l}\text { Geographic } \\
\text { Location }\end{array}$ & $\begin{array}{l}\text { Study } \\
\text { Design }\end{array}$ & $\begin{array}{l}\text { Disease } \\
\text { State/Focus }\end{array}$ & Setting \\
\hline 2018 [45] & $\begin{array}{l}\text { Blood-Pressure Reduction in } \\
\text { Black Barbershops }\end{array}$ & & $\begin{array}{l}54.4 \\
\text { Control: } 54.6 \\
35-79\end{array}$ & $\begin{array}{l}\text { educated, have } \\
\text { regular medical } \\
\text { provider and } \\
\text { insured }\end{array}$ & California & $\begin{array}{l}\text { Randomized } \\
\text { Control Trial }\end{array}$ & Disease & \\
\hline $\begin{array}{l}\text { Victor, } \\
2019[46]\end{array}$ & $\begin{array}{l}\text { Sustainability of Blood Pressure } \\
\text { Reduction in Black Barbershops }\end{array}$ & $n=319$ & $\begin{array}{l}\text { I: } 54.4 \\
\text { C: } 54.6 \\
35-79\end{array}$ & $\begin{array}{l}\text { mostly college } \\
\text { educated, have } \\
\text { regular medical } \\
\text { provider and } \\
\text { insured }\end{array}$ & $\begin{array}{l}\text { Los Angeles, } \\
\text { California }\end{array}$ & $\begin{array}{l}\text { Cluster } \\
\text { Randomized } \\
\text { Control Trial }\end{array}$ & $\begin{array}{l}\text { Cardiovascular } \\
\text { Disease }\end{array}$ & Barbershop \\
\hline
\end{tabular}

one by trained counselors and community health workers [21, 50, 55]. Intervention duration varied from 25 min (video) to 14 months. The use of Social Cognitive Theory (SCT) was reported in three studies [21, 27]; two studies cited Health Belief Model [29, 30]; one study employed the Personal Integrative Model of Prostate Cancer and the Health Communication Process model [52], one study utilized peer learning [44], and one study adapted a model from the AIDS Community Demonstration Project [56]. Only five studies explicitly stated using a community-based participatory research (CBPR) approach [27, 29, 50, 51, 53].

Barbershop/hair salon recruitment strategies were described for most of the studies. Five of the studies employed community agencies or existing community partnerships to recruit sites [29, 30, 50, 51, 53]. Three studies targeted certain geographical areas [27, 55, 56]. For two studies, hair stylists were assessed for fit with the mission of the project $[20,30]$. And one study reported specific criteria for selection of barbershops [56]. Aside from using the barbershop or hair salon as the primary site for interventions, other culturally adapted strategies used were tailoring materials (print/media) for African Americans and in some cases specifically by gender. Materials were either developed or tested by the target audience prior to use in the studies. Other tactics were ensuring interventionists and/or data collectors were African American. One study incorporated ancestral storytelling, a traditional African communication model, as a mechanism for the hair stylists to deliver the intervention message to their clients and subsequently to their clients' family and friends [30]. The majority of studies provided incentives to barbers/stylists and/or customers. Intervention content focused on the following topics: cancer (screening, prevention, treatment, medical provider engagement, access, risk factors, general knowledge), cardiovascular disease (blood pressure (BP)/hypertension (HTN) treatment, medical provider engagement, access), diabetes (screening, medical provider engagement, access, risk factors, general knowledge), obesity (physical activity, diet, water consumption), skill building, and self-efficacy to engage in the intended health behavior.

For interventions delivered by barbers or hair stylists $(n=8)$, details about intervention training and fidelity strategies are provided in Table 3 . Trainings were inperson and facilitated by the researcher/research staff and when appropriate medical or content professionals. Written materials (handbooks, brochures, scripts, etc.) were used to supplement trainings as well as ongoing/refresher trainings. Intervention fidelity strategies included on-site monitoring by research staff or a community research partner, regular quality assurance review of the data being collected, and researcher accessibility to the barbers/stylists for continued support. One study did not monitor fidelity throughout the intervention, but did post-study surveys and interviews with study participants to evaluate barber intervention delivery [56].

\section{Outcomes}

Primary, secondary, and feasibility outcomes data are presented in Table 4. There was significant heterogeneity in outcomes with most primary outcomes being behavioral and four studies reporting clinical outcomes related to $\mathrm{BP} / \mathrm{HTN}[21,44,45,56]$. Behavioral outcomes included clinic-based screening (completion/intent), home-based screening (self-exam), provider follow up (treatment, general conversation), physical activity (quantity), and diet (servings of fruit/vegetables and water consumption). Six studies reported significant between-group differences $[20,21,44,45,55,56]$ while two reported significant with-in group differences [52, 53]. All studies that reported changes in HTN treatment had significant findings. Two articles where each intervention served as the comparison for the other, reported significant outcomes related to cancer screening for both groups, but non-significant results for the diabetes screening (between-group and intervention). The interventions were identical in every aspect except content (specific to disease state) [29, 30].

Feasibility outcomes included as an exploratory focus for this review were not always explicitly stated, but 


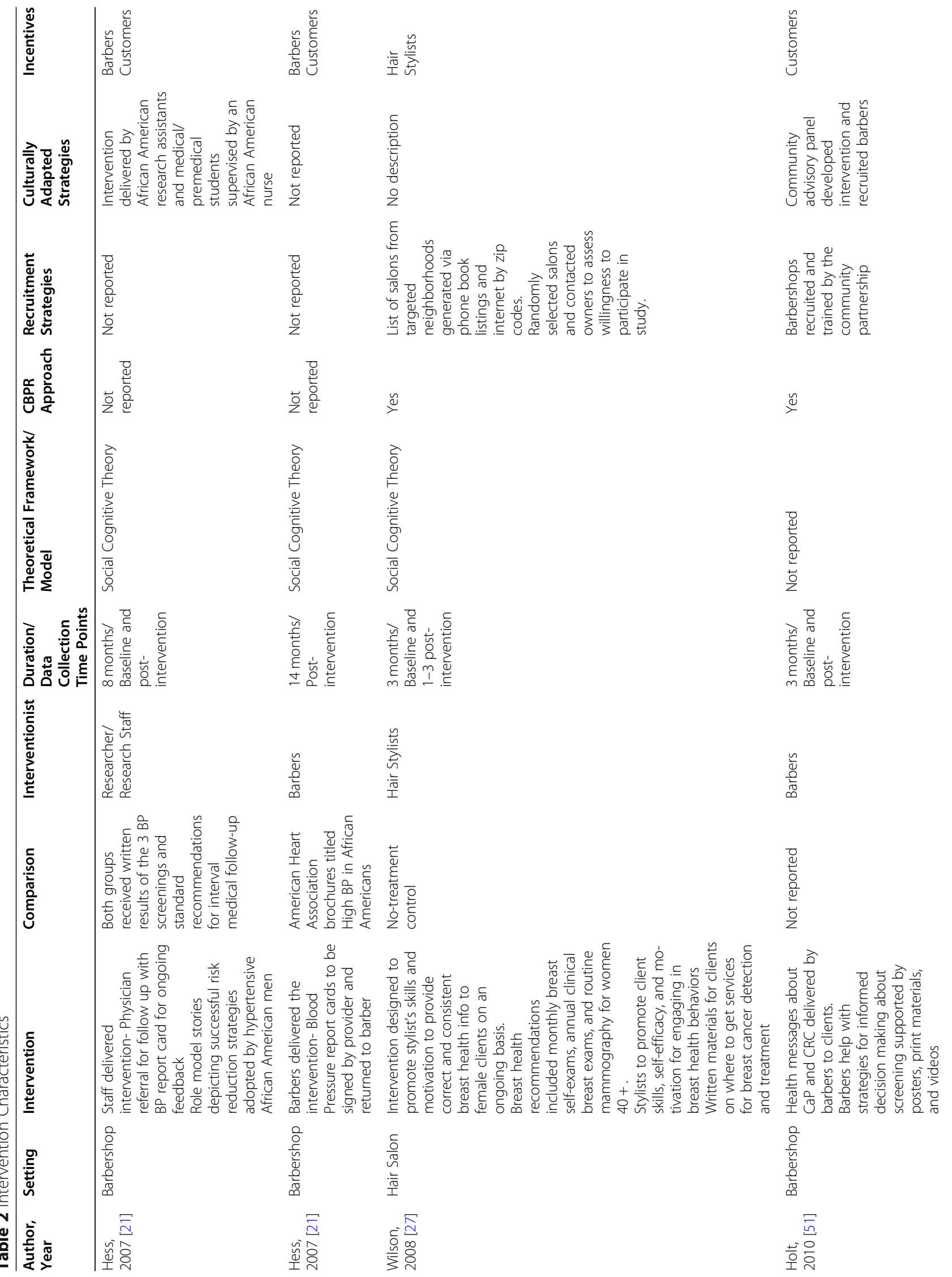




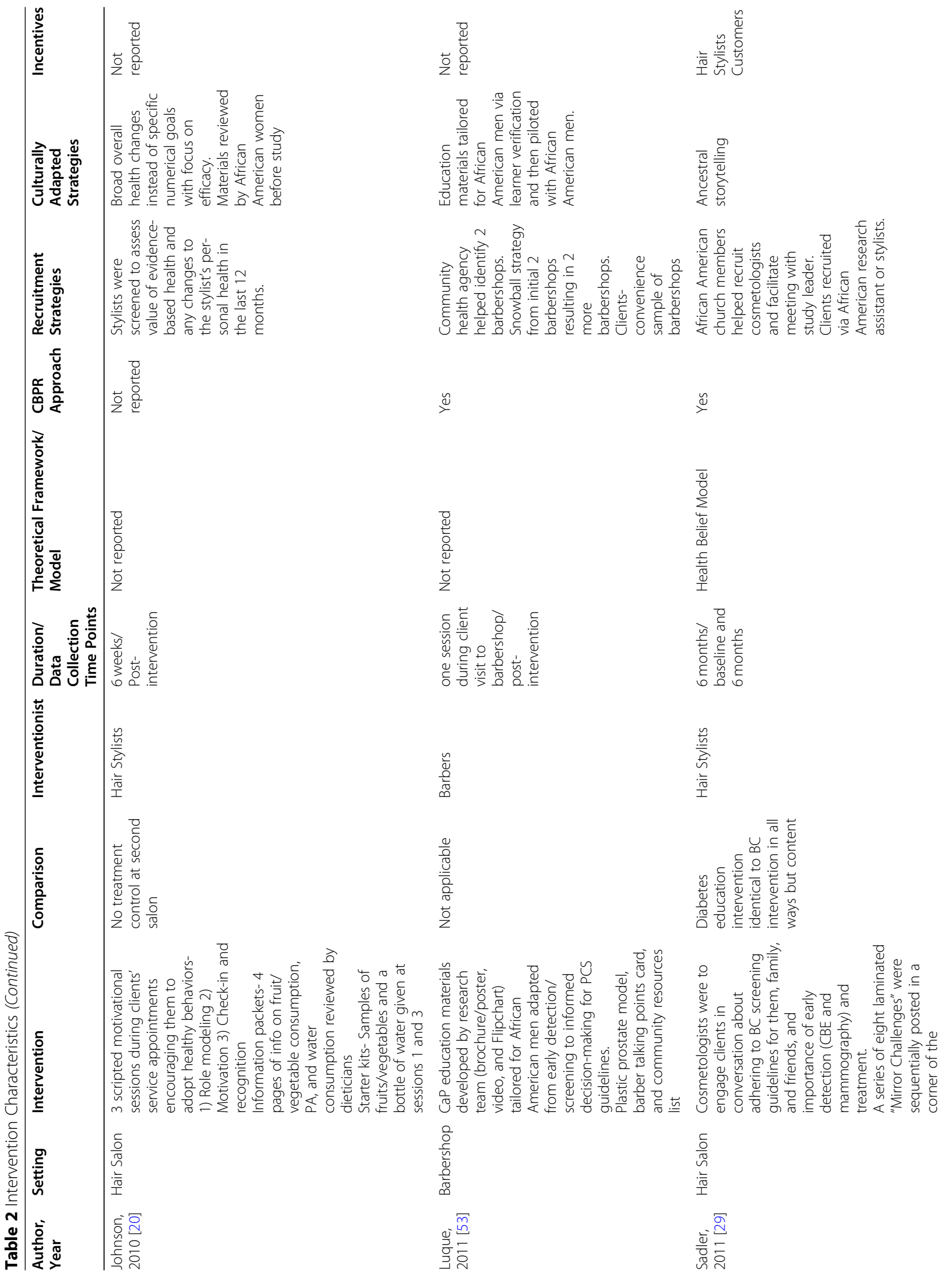




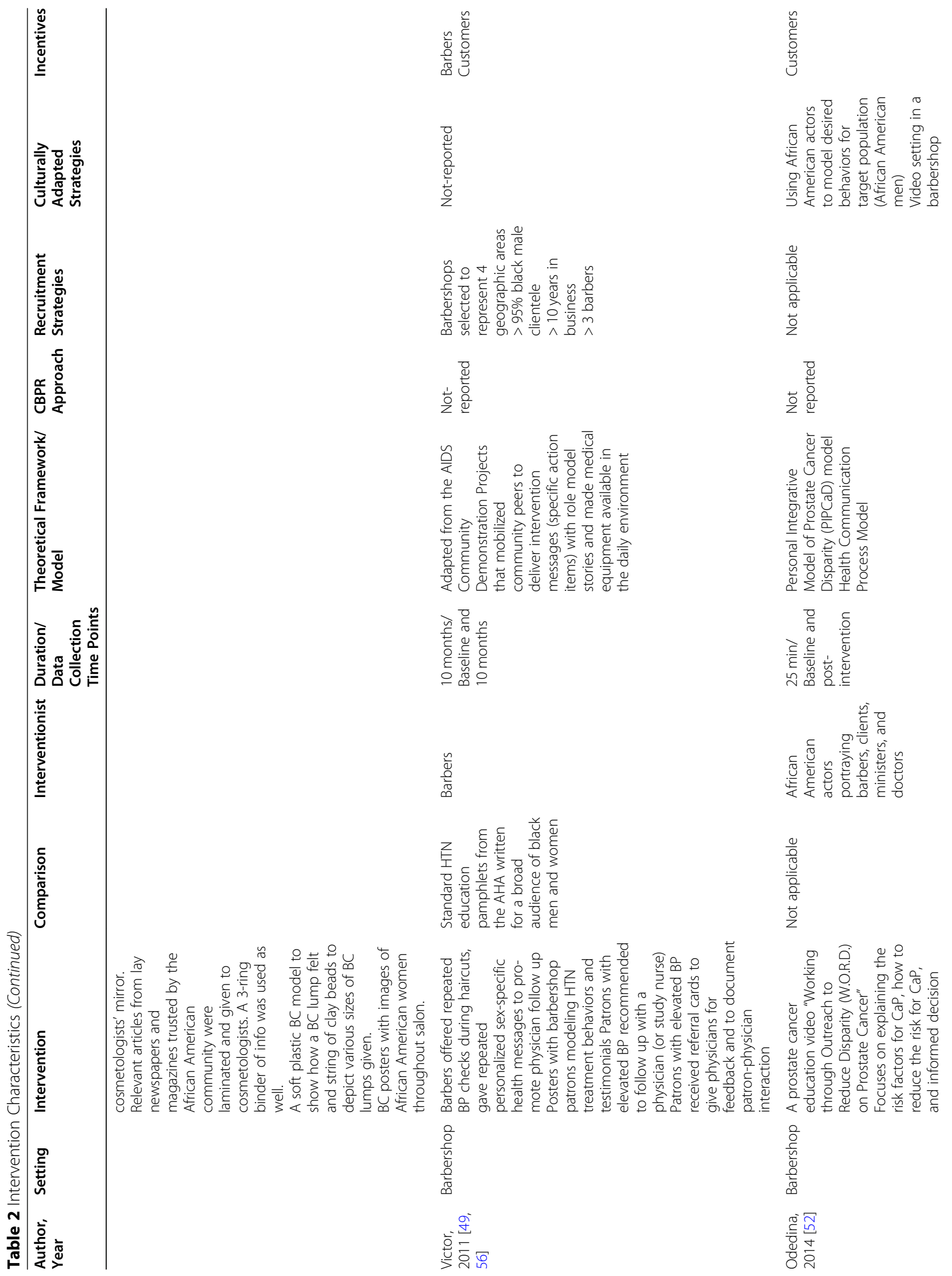




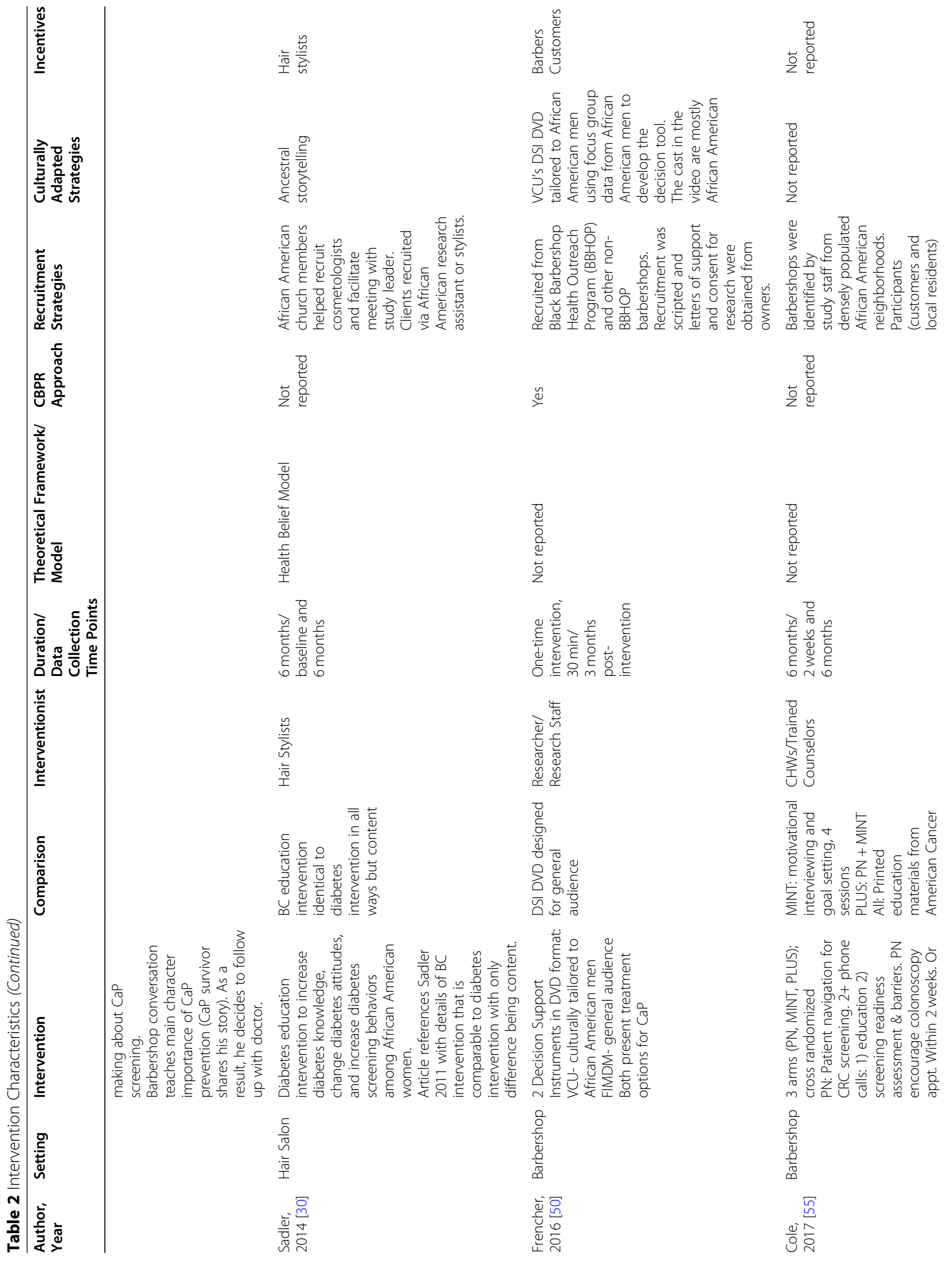




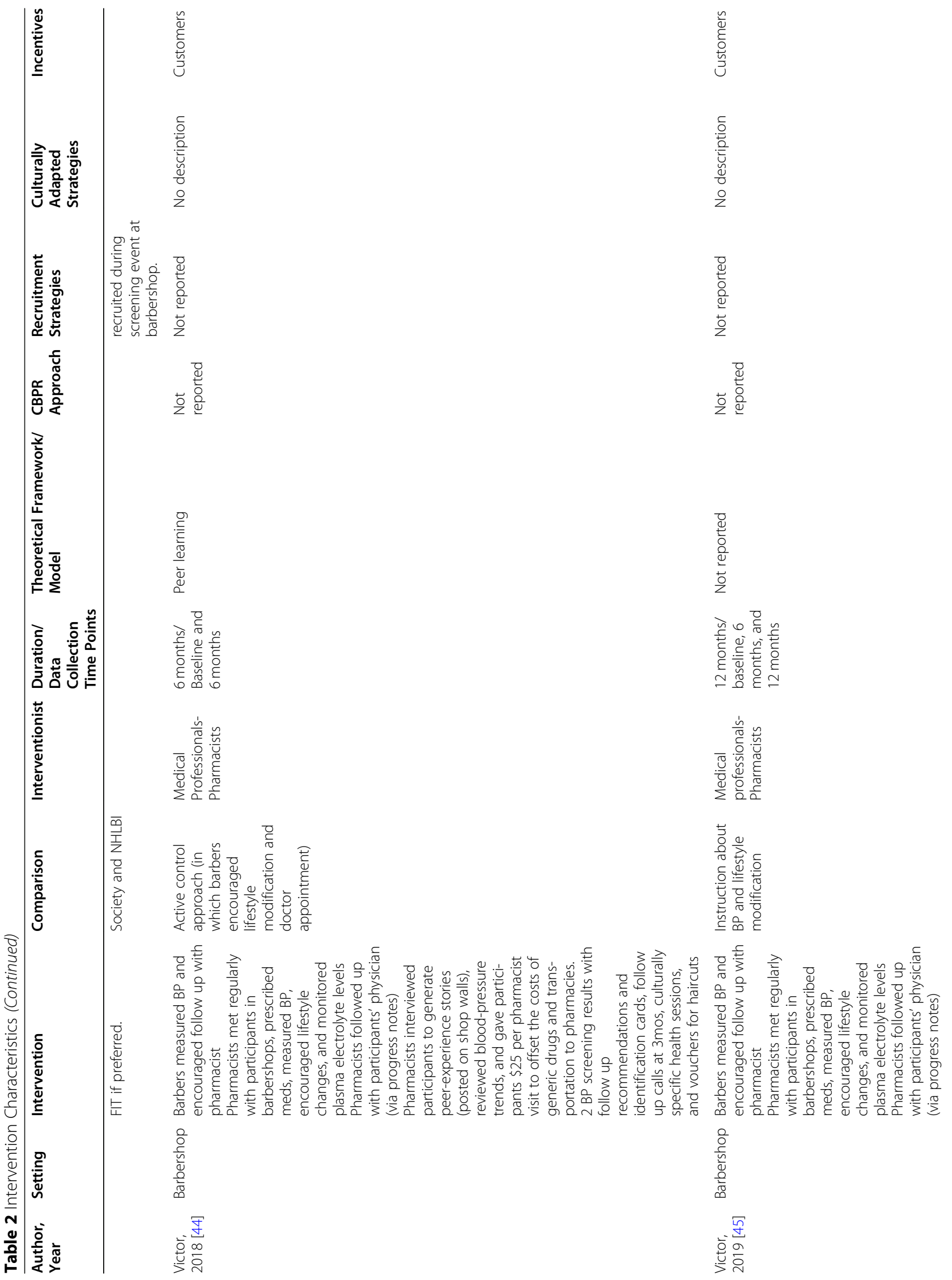




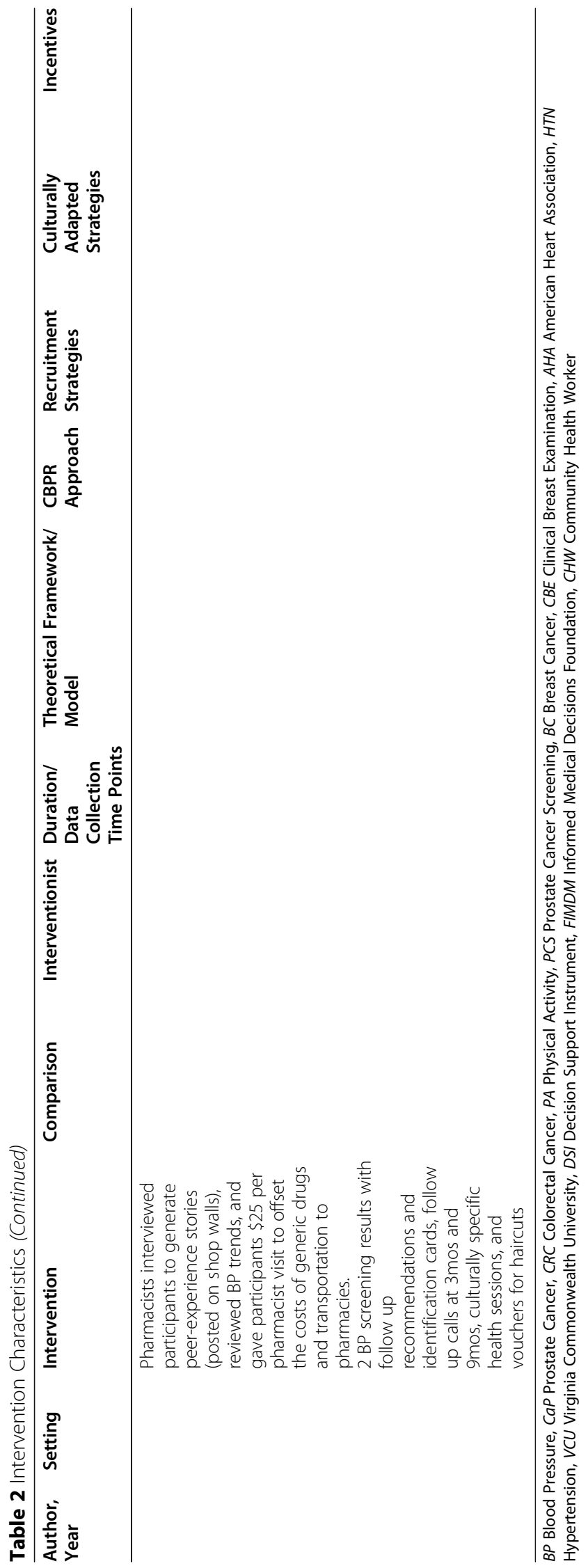


Table 3 Barber/Stylist Led Interventions

\begin{tabular}{|c|c|c|c|}
\hline $\begin{array}{l}\text { Author, } \\
\text { Year }\end{array}$ & $\begin{array}{l}\text { Interventionist/ } \\
\text { Setting }\end{array}$ & Intervention Training & Intervention Fidelity Strategies \\
\hline $\begin{array}{l}\text { Hess, } \\
2007[21]\end{array}$ & $\begin{array}{l}\text { Barbers/ } \\
\text { Barbershop }\end{array}$ & Not reported & $\begin{array}{l}\text { Research staff regularly checked the validity of the } \\
\text { encounter form data against data stored in the electronic } \\
\text { monitors and intermittently observed customer flow to } \\
\text { validate the barbers' counts of adult and child business. }\end{array}$ \\
\hline $\begin{array}{l}\text { Wilson, } \\
2008[27]\end{array}$ & $\begin{array}{l}\text { Hair Stylists/Hair } \\
\text { Salon }\end{array}$ & $\begin{array}{l}\text { Stylists were trained to conduct tailored and culturally } \\
\text { sensitive counseling that would encourage clients to } \\
\text { engage in breast health behaviors } \\
\text { 2, two-hour workshops, a reference handbook, and on- } \\
\text { going support and technical assistance by research staff. } \\
\text { Stylist training was implemented in waves, based on } \\
\text { planned initiation of intervention activities in that salon }\end{array}$ & $\begin{array}{l}\text { Program staff made frequent visits to salons to support } \\
\text { stylists in their promotion of message delivery throughout } \\
\text { the time during which the program was administered. }\end{array}$ \\
\hline $\begin{array}{l}\text { Holt, } \\
2010 \text { [49] }\end{array}$ & $\begin{array}{l}\text { Barbers/ } \\
\text { Barbershop }\end{array}$ & $\begin{array}{l}\text { Barbers trained by community advisory panel. } \\
\text { One day of training education training modules and } \\
\text { barbers given strategies for helping their clients make } \\
\text { informed decisions about screening }\end{array}$ & Did not collect/not report. \\
\hline $\begin{array}{l}\text { Johnson, } \\
2010[20]\end{array}$ & $\begin{array}{l}\text { Hair Stylists/Hair } \\
\text { Salon }\end{array}$ & $\begin{array}{l}\text { Stylists were trained by research team. } \\
\text { Motivational sessions using a script as a guide with } \\
\text { practice and feedback from research team member. }\end{array}$ & Weekly check-ins. \\
\hline $\begin{array}{l}\text { Luque, } \\
2011[50]\end{array}$ & $\begin{array}{l}\text { Barbers/ } \\
\text { Barbershop }\end{array}$ & $\begin{array}{l}10 \text { contact hours of training (didactic, interactive group, } \\
\text { and team building) on administering materials by research } \\
\text { team, health agency partners, and local urologist at } \\
\text { agency's facilities and in barbershops. }\end{array}$ & $\begin{array}{l}\text { Health agency partner monitored barbers via shop visits, } \\
\text { attended project meetings, and facilitated focus group } \\
\text { work with barbers for post-intervention evaluation. }\end{array}$ \\
\hline $\begin{array}{l}\text { Sadler, } \\
2011[29]\end{array}$ & $\begin{array}{l}\text { Hair Stylists/Hair } \\
\text { Salon }\end{array}$ & $\begin{array}{l}\text { Cosmetologists received } \sim 4 \mathrm{~h} \text { of } 1 \text {-on-1 training with the } \\
\text { Principal Investigator and an additional } 4 \mathrm{~h} \text { of reading ma- } \\
\text { terials that reviewed and summarized the Principal Investi- } \\
\text { gator's training. } \\
\text { The reading materials resources: National Cancer Institute, } \\
\text { American Cancer Society, and Susan G. Komen-for-the-Cure } \\
\text { Foundation. } \\
\text { Cosmetologists also received individual training from an } \\
\text { African American ancestral storyteller to enhance their } \\
\text { ability to pass along their health promotion messages } \\
\text { orally. } \\
\text { Every two weeks, the cosmetologists were given hands-on } \\
\text { training materials and shown ways the materials could be } \\
\text { used to facilitate discussions with their clients to keep the } \\
\text { screening message updated with fresh information }\end{array}$ & $\begin{array}{l}\text { Principal Investigator made unannounced visits to salons } \\
\text { every } 2 \text { weeks during the first } 3 \text { months and then monthly } \\
\text { thereafter to restock and bring new materials (for } \\
\text { consistency), offer training, and answer questions. } \\
\text { Principal Investigator was accessible to cosmetologists at } \\
\text { all times. }\end{array}$ \\
\hline $\begin{array}{l}\text { Victor, } \\
2011[27]\end{array}$ & $\begin{array}{l}\text { Barbers/ } \\
\text { Barbershop }\end{array}$ & Not reported & $\begin{array}{l}\text { Participant follow up survey and interview data on } \\
\text { intervention delivery by barbers. }\end{array}$ \\
\hline $\begin{array}{l}\text { Sadler, } \\
2014[30]\end{array}$ & $\begin{array}{l}\text { Hair Stylists/Hair } \\
\text { Salon }\end{array}$ & $\begin{array}{l}\text { IRB consent training. } \\
\text { Stylists received 1-on-1 training with the Principal Investiga- } \\
\text { tor and reading materials. } \\
\text { Stylists also received individual training from an African } \\
\text { American ancestral storyteller to enhance their ability to } \\
\text { pass along their health promotion messages orally. } \\
\text { The stylists were given ongoing training from the Principal } \\
\text { Investigator and participated in biannual luncheon } \\
\text { trainings. } \\
\text { Screening message updated with fresh information. }\end{array}$ & $\begin{array}{l}\text { Principal Investigator and research team made } \\
\text { unannounced visits to salons. } \\
\text { Principal Investigator was accessible via cell phone to } \\
\text { stylists at all times. }\end{array}$ \\
\hline
\end{tabular}

assessed the following areas: acceptability (satisfaction, intent to continue use), practicality (quality of implementation, effects on target audience, ability to carry out, cost analysis), integration, limited efficacy (effect size, intended effects on intermediate variables), and implementation (degree of execution, success or failure of execution). Implementation was the most assessed $(n=7)$ followed by acceptability $(n=5)$, practicality $(n=3)$, and limited efficacy $(n=3)$. Overall, studies reported favorable feasibility outcomes noting barbers/stylists' ability to deliver, barber/ stylists' degree of executing the interventions, and clients' satisfaction with interventions. In one study, 98\% of participants and all of the barbers expressed a desire to continue with the intervention [56]. One study performed a cost-analysis for a barber delivered hypertension intervention. In the cost-effectiveness model, the intervention was cost-neutral with the intervention costing $\sim \$ 50$ per barbershop patron [56]. 
Table 4 Outcomes

\begin{tabular}{|c|c|c|c|c|c|c|c|}
\hline $\begin{array}{l}\text { Author, } \\
\text { Year }\end{array}$ & Setting & $\begin{array}{l}\text { Primary } \\
\text { Outcomes }\end{array}$ & Primary Results & $\begin{array}{l}\text { Secondary } \\
\text { Outcomes }\end{array}$ & $\begin{array}{l}\text { Secondary Results } \\
\text { (Significant) }\end{array}$ & $\begin{array}{l}\text { Feasibility } \\
\text { Outcomes }\end{array}$ & Feasibility Results \\
\hline $\begin{array}{l}\text { Hess, } \\
2007 \text { [21] }\end{array}$ & Barbershop & $\begin{array}{l}\text { Change in BP } \\
\text { Changes in HTN } \\
\text { Treatment rate } \\
\text { (percentage of } \\
\text { hypertensive } \\
\text { subjects } \\
\text { receiving } \\
\text { prescription BP } \\
\text { medication) } \\
\text { HTN control rate }\end{array}$ & $\begin{array}{l}\text { I: BP fell } 16+/-3 / 9 \\
\text { +/- } 2 \mathrm{mmHg} \text { (systolic: } \\
149.1+/-2.2 \text { to } 133.4 \\
\text { +/- } 2.2 \mathrm{mmHg} \\
\text { diastolic: } 87.4+/- \\
2.6 \text { to } 78.82 .6 \mathrm{mmHg} \text { ) } \\
\text { C: Unchanged } \\
\text { (systolic: } 146.4+/-2.4 \\
\text { to } 146.7+/-2.4 \\
\text { mmHg; diastolic: } 87.9 \\
\text { +/- } 2.2 \text { to } 88.0+/- \\
2.2 \mathrm{mmHg}) \\
\text { Intervention } \\
\text { effectremained } \\
\text { significant }(P<0.0001) \\
\text { after adjustment for } \\
\text { age and body mass } \\
\text { index } \\
\text { I: HTN treatment } \\
\text { increased from } 47 \text { to } \\
\text { 92\% ( } P<0.001) \\
\text { C: Unchanged } \\
\text { I: HTN control } \\
\text { increased from } 19 \text { to } \\
\text { 58\% (P<0.001) } \\
\text { C: Unchanged }\end{array}$ & & & Implementation & $\begin{array}{l}\text { high percentage of } \\
\text { haircuts accompanied } \\
\text { by a BP recording, as } \\
\text { well as BP readings } \\
\text { interpreted correctly. }\end{array}$ \\
\hline $\begin{array}{l}\text { Hess, } \\
2007 \text { [21] }\end{array}$ & Barbershop & $\begin{array}{l}\text { Proportion of } \\
\text { haircuts in } \\
\text { which the } \\
\text { barber recorded } \\
\text { a BP }\end{array}$ & $\begin{array}{l}81 \% \text { haircuts barber } \\
\text { recorded a BP }\end{array}$ & $\begin{array}{l}\text { HTN control } \\
\text { rate }\end{array}$ & $\begin{array}{l}\text { HTN control rate } \\
\text { increased } \\
\text { progressively with } \\
\text { increasing levels of } \\
\text { intervention exposure: } \\
20+/-10.7 \% \text { to } 51+/- \\
9 \%(p=0.01) \\
\text { Association between } \\
\text { intervention exposure } \\
\text { and HTN control } \\
\text { remained significant } \\
\text { after controlling for } \\
\text { insurance status ( } p= \\
0.01)\end{array}$ & Implementation & $\begin{array}{l}\text { high percentage of } \\
\text { haircuts accompanied } \\
\text { by a BP recording } \\
\text { BP readings } \\
\text { interpreted correctly. } \\
\text { Barbers correctly } \\
\text { staged } 92 \% \text { of BPs }\end{array}$ \\
\hline $\begin{array}{l}\text { Wilson, } \\
2008 \text { [27] }\end{array}$ & Hair Salon & $\begin{array}{l}\text { Self-breast exam } \\
\text { (BSE) } \\
\text { completion } \\
\text { Clinical breast } \\
\text { exam (CBE) } \\
\text { completion } \\
\text { CBE intention } \\
\text { (12 months) } \\
\text { Mammogram } \\
\text { completion } \\
\text { Mammogram } \\
\text { intention (12 } \\
\text { months) }\end{array}$ & $\begin{array}{l}\text { BSE completion: AOR } \\
1.60 \text { (95\% Cl: 1.2-2.13) } \\
\text { CBE completion: AOR } \\
1.20 \text { (95\% Cl: 0.94- } \\
1.52 \text { ) } \\
\text { CBE intention: AOR } \\
1.87 \text { (95\% Cl: } 1.11- \\
\text { 3.13) } \\
\text { Mammogram } \\
\text { completion: AOR } 1.21 \\
\text { (95\% Cl: 0.84-1.76) } \\
\text { Mammogram } \\
\text { intention: AOR 1.34 } \\
\text { (95\% Cl: 0.9-1.2) }\end{array}$ & & & $\begin{array}{l}\text { Implementation- } \\
\text { degree of } \\
\text { execution }\end{array}$ & $\begin{array}{l}37 \% \text { intervention vs. } \\
10 \% \text { control reported } \\
\text { exposure to breast } \\
\text { health messages }\end{array}$ \\
\hline $\begin{array}{l}\text { Holt, } \\
2010 \text { [51] }\end{array}$ & Barbershop & $\begin{array}{l}\text { CaP screening/ } \\
\text { intent to screen } \\
\text { (PSA/DRE) } \\
\text { CRC screening/ } \\
\text { intent to screen } \\
\text { (FOBT/FS/CS) }\end{array}$ & $\begin{array}{l}\text { Possible increases in } \\
\text { self-reported PSA test } \\
\text { and prep for PSA and } \\
\text { DRE. } \\
\text { I: constantly greater } \\
\text { increase in awareness, } \\
\text { screening, and prep } \\
\text { for FS }\end{array}$ & $\begin{array}{l}\text { CaP } \\
\text { knowledge } \\
\text { CRC } \\
\text { knowledge } \\
\text { CRC } \\
\text { screening } \\
\text { perceived } \\
\text { barriers and } \\
\text { benefits }\end{array}$ & Results not significant & Not reported & Not reported \\
\hline $\begin{array}{l}\text { Johnson, } \\
2010[20]\end{array}$ & Hair Salon & $\begin{array}{l}\text { Increase in fruit } \\
\text { and vegetable }\end{array}$ & $\begin{array}{l}\text { Fruit and vegetable } \\
\text { intake increased from }\end{array}$ & & & Not reported & Not reported \\
\hline
\end{tabular}


Table 4 Outcomes (Continued)

\begin{tabular}{|c|c|c|c|c|c|c|c|}
\hline $\begin{array}{l}\text { Author, } \\
\text { Year }\end{array}$ & Setting & $\begin{array}{l}\text { Primary } \\
\text { Outcomes }\end{array}$ & Primary Results & $\begin{array}{l}\text { Secondary } \\
\text { Outcomes }\end{array}$ & $\begin{array}{l}\text { Secondary Results } \\
\text { (Significant) }\end{array}$ & $\begin{array}{l}\text { Feasibility } \\
\text { Outcomes }\end{array}$ & Feasibility Results \\
\hline & & $\begin{array}{l}\text { consumption } \\
\text { Increase in } \\
\text { physical activity } \\
\text { Increase in } \\
\text { water } \\
\text { consumption }\end{array}$ & $\begin{array}{l}\text { pre-posttest for the } \\
\text { treatment group } \\
\text { No increase in } \\
\text { physical activity } \\
\text { No increase in water } \\
\text { consumption }\end{array}$ & & & & \\
\hline $\begin{array}{l}\text { Luque, } \\
2011 \text { [53] }\end{array}$ & Barbershop & $\begin{array}{l}\text { Likelihood of } \\
\text { discussing CaP } \\
\text { with healthcare } \\
\text { provider (4- } \\
\text { point Likert } \\
\text { scale (very } \\
\text { unlikely to very } \\
\text { likely)) } \\
\text { CaP knowledge } \\
\text { ( } 5 \text { pt. Likert scale } \\
\text { (low to high)) }\end{array}$ & $\begin{array}{l}\text { Somewhat likely to } \\
\text { very likely Increased } \\
\text { from } 75 \text { to } 85 \% \\
p<.001 \\
78 \% \text { reported increase } \\
\text { in knowledge }\end{array}$ & $\begin{array}{l}\text { Feelings of } \\
\text { worry about } \\
\text { CaP ( } 4 \text { pt. } \\
\text { Likert not } \\
\text { worried to } \\
\text { very worried) } \\
\text { Projected } \\
\text { PCS modality } \\
\text { intention } \\
\text { (PSA, DRE, or } \\
\text { both) }\end{array}$ & $\begin{array}{l}\text { Somewhat worried to } \\
\text { very worried increased } \\
\text { from } 35 \text { to } 45 \% \text {. } \\
p<.001 \\
85 \% \text { - Both (PSA \& } \\
\text { DRE) }\end{array}$ & $\begin{array}{l}\text { Satisfaction with } \\
\text { the intervention } \\
\text { Intention to } \\
\text { continue the } \\
\text { intervention } \\
\text { Expansion and } \\
\text { implementation }\end{array}$ & $\begin{array}{l}\text { Participants reported } \\
\text { that the materials } \\
\text { were easy to } \\
\text { understand, had an } \\
\text { attractive color } \\
\text { scheme, and featured } \\
\text { familiar faces printed } \\
\text { on the materials. } \\
\text { All barbershop clients } \\
\text { surveyed reported } \\
\text { positively on the } \\
\text { contents of the } \\
\text { brochure and poster } \\
53 \% \text { had discussed } \\
\text { CaP at least two times } \\
\text { with their barber in } \\
\text { the last month }\end{array}$ \\
\hline $\begin{array}{l}\text { Sadler, } \\
2011 \text { [29] }\end{array}$ & Hair Salon & $\begin{array}{l}\text { Adherence to } \\
\text { Mammography } \\
\text { screening } \\
\text { guidelines }\end{array}$ & $\begin{array}{l}\text { IT between groups at } \\
\text { follow up not } \\
\text { significant } \\
\text { ITT for mammography } \\
\text { completers in both } \\
\text { groups significantly } \\
\text { ( } p<.05 \text { ) higher at } \\
\text { follow up. } \\
\text { Adjusting for age } \\
\text { (40+) as covariate } \\
\text { yielded adherence to } \\
\text { screening OR } 2.0 \text { ( } 95 \% \\
\text { Cl: } 1.03-3.85 \text { ) times } \\
\text { higher for I vs C }\end{array}$ & $\begin{array}{l}\text { Clinical } \\
\text { breast exam } \\
\text { adherence } \\
\text { Participants' } \\
\text { awareness } \\
\text { and } \\
\text { perceptions } \\
\text { of their } \\
\text { vulnerability } \\
\text { for breast } \\
\text { cancer }\end{array}$ & $\begin{array}{l}\text { ITT for perception of } \\
\text { seriousness of } B C \text { as } \\
\text { health threat reduced } \\
\text { significantly }(\mathrm{p}<.05) \\
\text { in both groups, but } \\
\text { greater reduction in } \\
\text { diabetes arm. OR of } \\
\text { listing } \mathrm{BC} \text { as threat } 1.8 \\
\text { times higher in } \mathrm{BC} \\
\text { arm ( } 95 \% \mathrm{Cl}: 1.0-3.1) \text {. }\end{array}$ & $\begin{array}{l}\text { Practicality } \\
\text { Implementation- } \\
\text { degree of } \\
\text { execution }\end{array}$ & $\begin{array}{l}57 \% \text { of the women } \\
\text { reported that health } \\
\text { education materials } \\
\text { were displayed in } \\
\text { their salon } \\
57 \% \text { participants } \\
\text { reported that the } \\
\text { cosmetologists in their } \\
\text { salon were offering } \\
\text { health information to } \\
\text { their clients } \\
80 \% \text { of the women } \\
\text { felt cosmetologists } \\
\text { could effectively carry } \\
\text { out intervention }\end{array}$ \\
\hline $\begin{array}{l}\text { Victor, } \\
2011 \text { [49, } \\
56]\end{array}$ & Barbershop & $\begin{array}{l}\text { Change in HTN } \\
\text { control rates (BP } \\
\text { measurements } \\
\text { and prescription } \\
\text { labels) } \\
\text { Patron-physician } \\
\text { follow up } \\
\text { interaction } \\
\text { (signed referral } \\
\text { card) }\end{array}$ & $\begin{array}{l}\text { Greater HTN control in } \\
\text { I vs C } \\
\text { Intervention effect: } \\
\text { Absolute group } \\
\text { difference- } 8.8 \%(95 \% \\
\text { Cl: } 0.8-16.9 ; \\
\text { Unadjusted: } p=.04 \\
\text { Adjusted } p=.03) \\
\text { Intervention effect: } \\
\text { ITT- } 7.8 \%(95 \% \mathrm{Cl}: 0.4- \\
15.3 ; p=.04)\end{array}$ & $\begin{array}{l}\text { Barbershop- } \\
\text { level } \\
\text { changes in } \\
\text { HTN } \\
\text { treatment } \\
\text { rates } \\
\text { HTN } \\
\text { awareness } \\
\text { BP levels }\end{array}$ & Results not significant & $\begin{array}{l}\text { Satisfaction with } \\
\text { the intervention } \\
\text { Intention to } \\
\text { continue the } \\
\text { intervention } \\
\text { Practicality } \\
\text { Implementation } \\
\text { and Penetration }\end{array}$ & $\begin{array}{l}83 \% \text { patrons heard a } \\
\text { model story during } \\
\text { every one or half their } \\
\text { haircuts from barber } \\
77 \% \text { patrons received } \\
\text { BP measurement from } \\
\text { barber } \\
51 \% \text { patrons with } \\
\text { elevated BP received } \\
\text { counseling/physician } \\
\text { referral from barber } \\
98 \% \text { patrons and all } \\
29 \text { barbers would like } \\
\text { the intervention to } \\
\text { continue } \\
\text { Cost analysis- Cost } \\
\text { effectiveness- cost- } \\
\text { neutral for health care } \\
\text { system would be } \$ 50 / \\
\text { patron }\end{array}$ \\
\hline $\begin{array}{l}\text { Odedina, } \\
2014[52]\end{array}$ & Barbershop & $\begin{array}{l}\text { CaP screening } \\
\text { CaP knowledge } \\
\text { Decisional } \\
\text { conflict }\end{array}$ & $\begin{array}{l}\text { CaP Screening } \\
\text { intention: } 12.78 \text { (2.48) } \\
\text { to } 13.37(2.13) \\
p=.0001 \\
\text { CaP knowledge: } 63.60 \\
(22.20) \text { to } 74.00(16.80) \\
p=0.0021\end{array}$ & $\begin{array}{l}\text { Intervention } \\
\text { effects }\end{array}$ & $\begin{array}{l}\text { Completion of PN } \\
\text { Intervention was } \\
\text { significantly associated } \\
\text { with study completion } \\
\text { and CRC screening }\end{array}$ & $\begin{array}{l}\text { Satisfaction with } \\
\text { the intervention } \\
\text { Limited Efficacy }\end{array}$ & $\begin{array}{l}>90 \% \text { of the } \\
\text { participants indicated } \\
\text { that they were } \\
\text { satisfied with the } \\
\text { video } \\
\text { The mean satisfaction } \\
\text { rating was } 13.67 \text { on a }\end{array}$ \\
\hline
\end{tabular}


Table 4 Outcomes (Continued)

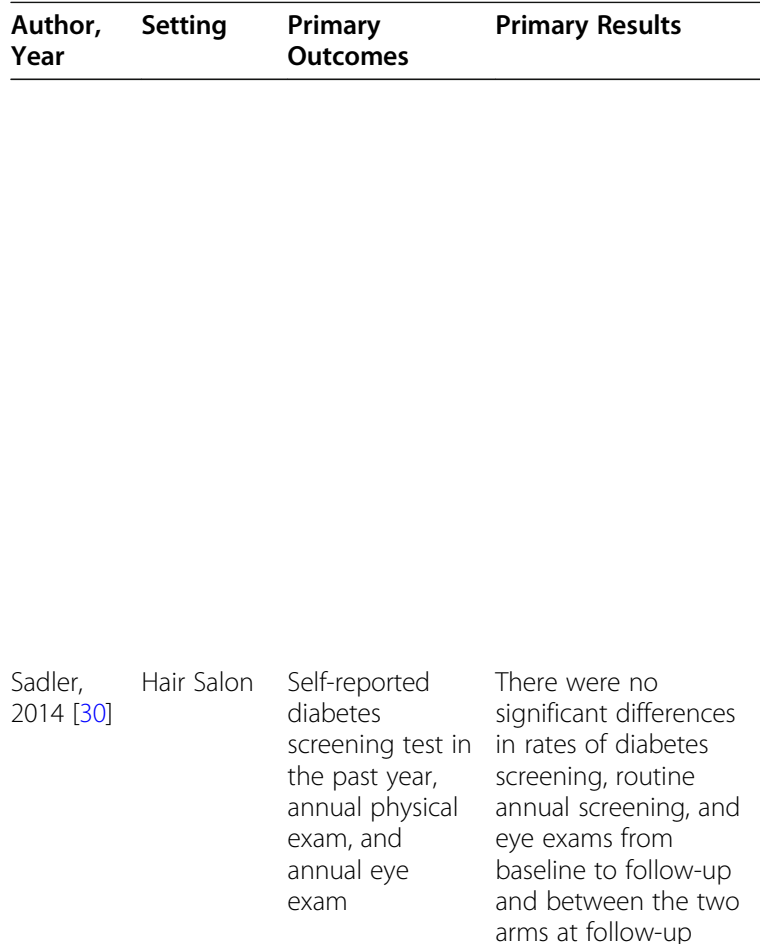

Frencher, Barbershop CaP screening $n=58$ completed PSA 2016 [50] via PSA test

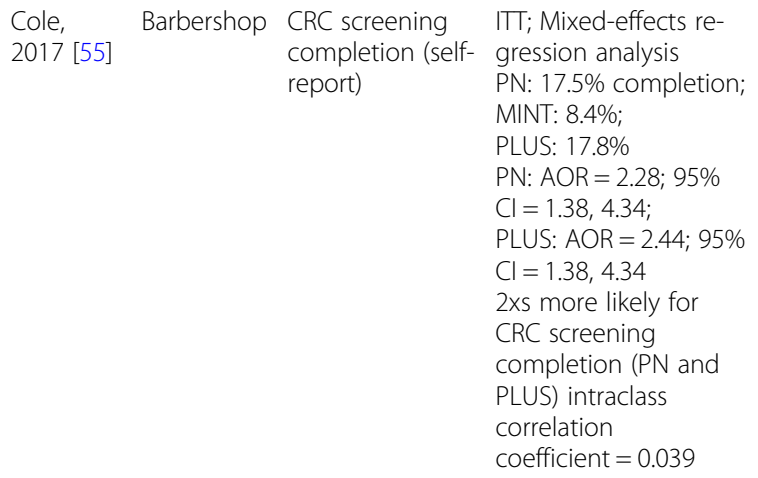

$\begin{array}{llll}\text { Changes in } & \text { Mean reduction in } & \text { Limited Efficacy } & 7 \text { in-person pharma- } \\ \text { DBP } & \text { DBP } 14.9 \mathrm{mmHg}>\text { in I } & \text { Implementation- } & \text { cist visits and } 4 \text { follow } \\ \text { Rates of } & \text { VS } C(95 \% \mathrm{Cl}, 10.3 \text { to } & \text { degree of } & \text { up calls per } \\ \text { meeting BP } & 19.6 ; \mathrm{P}<0.001) & \text { execution } & \text { participant } \\ \text { goals } & \text { I: higher } \% \text { of meeting } & & 6 \text { calls/messages to } \\ \text { Numbers of } & \text { BP goals } & \text { pharmacist per } \\ \text { hypertensive } & \text { I: Increases in use of } & \text { participant } \\ \text { meds } & \text { antihypertensive } & 4 \text { BP } \\ \text { Adverse drug } & \text { meds: } 55-100 \% ; & \text { Checks per participant }\end{array}$

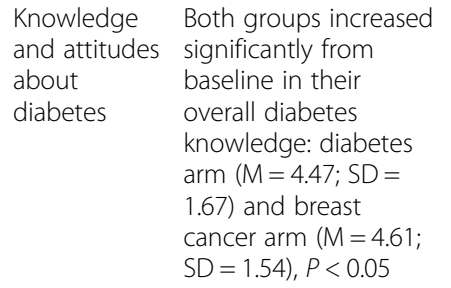
and attitudes significantly from about diabetes baseline in their overall diabetes knowledge: diabetes $\operatorname{arm}(M=4.47 ; S D=$ 1.67) and breast cancer arm $(M=4.61$; $\mathrm{SD}=1.54), P<0.05$

Changes in knowledge and intention- all significant Intention to screenincreased from 57 to $73 \%$

Overall- no between group differences scale ranging from 3 to 15 , indicating a highly satisfactory rating for the video $>75 \%$ of the participants indicated that the video: 1) was useful, 2) was understood, 3) not embarrassing, 4) was not too long, 5) not difficult, 6) was relevant, 7) got their attention, 8) has potential to increase CaP knowledge for African American men, and 9) was credible

$75 \%$ reported attending salon where health education was being offered. $65 \%$ reported cosmetologist made health info available $41 \%$ shared info w with family and friends 92\% feel cosmetologist could effectively deliver diabetes information

$\begin{array}{ll}\text { and } & \text { knowledge and } \\ \text { intention } & \text { significant } \\ & \text { Intention to screen- } \\ & \text { increased from } 57 \text { to } \\ & 73 \% \\ & \text { Overall- no between } \\ & \text { group differences }\end{array}$

Not reported Not reported 
Table 4 Outcomes (Continued)

\begin{tabular}{|c|c|c|c|c|c|c|c|}
\hline $\begin{array}{l}\text { Author, } \\
\text { Year }\end{array}$ & Setting & $\begin{array}{l}\text { Primary } \\
\text { Outcomes }\end{array}$ & Primary Results & $\begin{array}{l}\text { Secondary } \\
\text { Outcomes }\end{array}$ & $\begin{array}{l}\text { Secondary Results } \\
\text { (Significant) }\end{array}$ & $\begin{array}{l}\text { Feasibility } \\
\text { Outcomes }\end{array}$ & Feasibility Results \\
\hline & & & $\begin{array}{l}\text { than C } \\
(95 \% \text { Cl: 14.0, 28.0); } \\
p<.001\end{array}$ & $\begin{array}{l}\text { reactions } \\
\text { Self-rated } \\
\text { health } \\
\text { Patient } \\
\text { engagement }\end{array}$ & C: $53-63 \%(p<.001)$ & & $\begin{array}{l}\text { by barber } \\
4 \text { health lessons per } \\
\text { participant by barber }\end{array}$ \\
\hline $\begin{array}{l}\text { Victor, } \\
2019 \text { [45] }\end{array}$ & Barbershop & Change in SBP & $\begin{array}{l}\text { I: } \text { mean reduction }= \\
28.6 \mathrm{mmHg} \\
\text { C: } \text { mean reduction = } \\
7.2 \mathrm{mmHg} \\
\text { Mean SBP reduction } \\
20.8 \mathrm{mmHg}>\text { I vs } \mathrm{C} \\
(95 \% \mathrm{Cl}: 13.9,27.7 ; \\
\text { p }<0.0001) \\
\text { ITT intervention effect: } \\
20.6 \mathrm{mmHg} \text { reduction } \\
(95 \% \mathrm{Cl}: 13.8,27.3 ; \\
p<0.0001)\end{array}$ & $\begin{array}{l}\text { Changes in } \\
\text { DBP } \\
\text { Rates of } \\
\text { meeting BP } \\
\text { goals } \\
\text { Numbers of } \\
\text { hypertensive } \\
\text { meds } \\
\text { Adverse drug } \\
\text { reactions } \\
\text { Self-rated } \\
\text { health } \\
\text { Patient } \\
\text { engagement }\end{array}$ & $\begin{array}{l}\text { Mean DBP reduction } \\
14.5 \mathrm{mmHg}>\text { I vs C } \\
(95 \% \mathrm{Cl}, 9.5-19.5 \\
\mathrm{mmHg} ; \mathrm{P}<0.0001) \\
\text { I: higher } \% \text { of meeting } \\
\mathrm{BP} \text { goals (68\% vs } 11 \% \text {; } \\
p=0.0177) \\
\text { I: Increase in use of } \\
\text { antihypertensive } \\
\text { meds: } 57 \text { to } 100 \% \\
\mathrm{C}: 53 \text { to } 65 \% \\
\text { No treatment-related } \\
\text { adverse events/deaths } \\
\text { I: Greater increase in } \\
\text { self-rated health and } \\
\text { patient engagement } \\
\text { scores }\end{array}$ & $\begin{array}{l}\text { Limited Efficacy } \\
\text { Implementation- } \\
\text { degree of } \\
\text { execution }\end{array}$ & $\begin{array}{l}11 \text { in-person pharma- } \\
\text { cist visits }(0-6 \\
\text { months }=4 ; 7-12 \\
\text { months }=4) \\
4 \text { BP checks per } \\
\text { participant by barber } \\
4 \text { health lessons per } \\
\text { participant by barber }\end{array}$ \\
\hline
\end{tabular}

BP Blood Pressure, SBP Systolic Blood Pressure, DBP Diastolic Blood Pressure, I Intervention, C Control, CaP Prostate Cancer, CRC Colorectal Cancer, PA Physical Activity, PCS Prostate Cancer Screening, PSA Prostate Specific Antigen, DRE Digital Rectal Examination, FOBT Fecal Occult Blood Test, FS Flexible Sigmoidoscopy, CS Colonoscopy, BC Breast Cancer, CBE Clinical Breast Examination, BSE Breast Self-Examination, HTN Hypertension, ITT Intention to Treat

\section{Quality of evidence}

Global evidence quality ratings for each study appear in Table 5. Guided by the EPHPP evaluation process, studies were rated on the following six components: selection bias, study design, confounders, blinding, data collection methods, and withdrawals/dropouts. The global rating for each study was determined based on the total number of component "weak" ratings. One study was rated as "strong," [56] two rated as "moderate," [44, 45] and eleven rated as "weak."
[20, 21, 27, 29, 30, 50-53, 55] Many of the studies that had a global rating of "weak" had non-RCT study designs resulting in a "moderate" or "weak" study design rating and components that did not apply/could not be rated accordingly. Because most participants were self-referred, many studies rated "weak" on selection bias. Oftentimes, studies did not report on blinding or on validation/reliability of data collection instruments and therefore received component ratings of "weak." Most studies controlled for

Table 5 Quality of Evidence

\begin{tabular}{lll}
\hline Author, Year & Study Design & EPHPP Global Quality Assessment Rating \\
\hline Hess, $2007[21]$ & Non-Randomized Feasibility & Weak \\
Hess, $2007[21]$ & Non-Randomized Feasibility & Weak \\
Wilson, $2008[27]$ & Cluster Randomized Control Trial & Weak \\
Holt, $2010[51]$ & 2 group Pretest-Posttest & Weak \\
Johnson, $2010[20]$ & 2 group Pretest-Posttest & Weak \\
Luque, $2011[53]$ & 1 group Posttest only & Weak \\
Sadler, $2011[29]$ & Cluster Randomized Control Trial & Weak \\
Victor, $2011[49,56]$ & Cluster Randomized Control Trial & Strong \\
Odedina, $2014[52]$ & 1 group Pretest-Posttest & Weak \\
Sadler, $2014[30]$ & Cluster Randomized Control Trial & Weak \\
Frencher, 2016 [50] & 2 group Pretest-Posttest & Weak \\
Cole, 2017 [55] & Randomized Control Trial & Weak \\
Victor, $2018[44]$ & Cluster Randomized Control Trial & Moderate \\
Victor, $2019[45]$ & Cluster Randomized Control Trial & Moderate \\
\hline
\end{tabular}


confounders during analysis yielding "strong" component ratings.

\section{Discussion}

With the disproportionate rates of obesity-related chronic diseases in the African American community, there is an imperative need to better elucidate strategies for engagement in health promotion interventions. Due to historically unethical medical and research practices in the U.S., African Americans have a longstanding history of mistrust of the medical and research community resulting in low participation and engagement, furthering the gap in health $[8,57,58]$. To remedy this, the use of culturally "safe" spaces such as churches, barbershops, and hair salons for recruitment and engagement of African Americans into research studies and lifestyle/behavioral interventions have become increasingly popular [59-61]. To this end, designing interventions to be delivered in trusted, culturally significant settings are advantageous. Barbershops and hair salons are highly accessed, cultural staples in the African American community perfectly situated to tackle the health disparities that plague this community.

This is the first review to synthesize the effectiveness and feasibility of obesity-related chronic disease interventions targeted for African Americans delivered in barbershops and hair salons. Eight of the fourteen studies included in this review reported significant results for clinical and/or behavioral outcomes suggesting that interventions delivered in barbershops and hair salons may be effective for reducing risk factors for or improving health outcomes of obesity-related chronic conditions in African Americans. Of these studies, half used an RCT design, the most rigorous methodology for establishing effectiveness. However, only one of these studies received a "strong" global quality assessment rating, while two received a rating of "moderate" and one received a rating of "weak" due to deficiencies in blinding and selection bias, data collection methods and reporting of withdrawals/dropouts, respectively. This coupled with the variability of duration for interventions point to the need for more efficacious research with considerations for the nuances of community-based study designs.

Among the research with significant results, the outcomes are split evenly between clinical and behavioral. Clinical interventions focused on changes in blood pressure and HTN management while behavioral interventions that can support clinical outcomes included cancer (prostate and colorectal) screening. Furthermore, half of these interventions were delivered or supported by the barbers/hair stylists. Considered together, these details suggest that barbershop/hair salon-based interventions can have a valuable direct or indirect impact in health promotion research. Most studies evaluated feasibility elements, but those were not among primary outcomes nor did any studies compare intervention components such as setting (i.e. barbershop versus church/clinic/ other community site) or interventionist (i.e. barber versus clinician/community health worker/researcher). One study where the researcher was the interventionist was replicated by the study team using the barber as the interventionist, but outcomes reported differed [21]. Future research would also benefit from examining the association of racial and gender congruence between the barber/stylist interventionist and clients and the desired outcomes. More research is needed to disentangle which components of the interventions are influencing outcomes.

\section{Limitations}

There are some limitations of this systematic review. The heterogeneity of the studies (study designs, sample sizes, intervention characteristics, and outcomes) made it difficult to compare the effectiveness of intervention strategies. This was due in part to the inclusion of multiple disease states, however, there were small number of studies identified through a comprehensive search strategy. However, limiting the search to one disease state or outcome would have further restricted the number of relevant articles for inclusion. Smaller, non-RCT, shortterm studies of moderate and weak quality did not support the evidence for or against the efficacy of barbershop/salon-based interventions. Self-reported data could have overpredicted effectiveness of interventions. Another limitation is that seven of the studies were conducted by the same three lead authors (three by one, two by one, and two by one) indicating potential publication bias. Finally, generalizability of the studies' findings is questionable given most studies were conducted in large, urban cities with participants of higher socioeconomic status.

\section{Conclusions}

Health promotion interventions delivered in barbershops and hair salons for African Americans appear to be modestly effective for reducing risk and improving health outcomes for obesity-related chronic diseases. Overall, the literature in this area is limited and varies in foci. The extent to which the barber/stylist is utilized warrants further investigation. Objective measurements could enhance results. While barbershops have been shown to be effective locations for recruitment of African American men, who have been the target audience for such interventions due to the difficulty with recruiting and engagement in health promotion interventions, research in hair salons with African American women deserves more attention. Moreover, interventions that address complex, layered behavior change associated 
with obesity and diabetes are needed while balancing the appropriateness of desired outcomes (behavioral versus clinical). While all community-based research can be involved and complicated, it can be gleaned from this literature that barbershops/hair salon-based interventions are feasible. The barbershop/hair salon and to a further extent, the barber and hair stylist, can serve to support the implementation of existing evidence-based interventions, possibly in partnership with the health care system, to address obesity and chronic disease health inequities for African Americans.

\begin{abstract}
Abbreviations
BP: Blood pressure; CBPR: Community-based participatory research; EPHPP: Effective Public Health Practice Project Quality Assessment Tool; HTN: Hypertension; NHW: Non-Hispanic whites; PRISMA: Preferred Reporting Items for Systematic Reviews and Meta-Analyses; PROSPERO: International Prospective Register of Systematic Reviews; RCT: Randomized control trial; REDCap: Research Electronic Data Capture; SCT: Social cognitive theory; SES: Socioeconomic status; U.S.: United States
\end{abstract}

\section{Supplementary Information}

The online version contains supplementary material available at https://doi. org/10.1186/s12889-021-11584-0.

Additional file 1. Search strategy.

Additional file 2. Data extraction form.

Additional file 3. Quality assessment form.

\section{Acknowledgments}

We would like to thank our colleagues for their continuous support.

\section{Authors' contributions}

KP designed and drafted the review manuscript, registered the review, coordinated the review process, and is the guarantor of the systematic review. $K P, J M, J H, D M, C T$, and DG contributed to the review's initial conception. KP, JM, and DG developed the search strategies and performed the search. KP, PR, and FM reviewed studies for inclusion, and extracted and analyzed data. JH, DM, CT, and DG revised and edited the manuscript. All authors have read and approved the final manuscript.

\section{Funding}

This study was supported with funds from the University of Arizona Health Sciences Center for Border Health Disparities through a paid subscription to Covidence for data collection.

\section{Availability of data and materials}

The datasets used for the current study are available from the corresponding author on reasonable request.

\section{Declarations}

Ethics approval and consent to participate

Not applicable.

\section{Consent for publication}

Not applicable.

\section{Competing interests}

The authors have no competing interests to declare.

\section{Author details}

${ }^{1}$ Department of Health Promotion Sciences, Mel and Enid Zuckerman College of Public Health, University of Arizona, 1295 N Martin Avenue, Tucson, AZ 85721-0202, USA. ${ }^{2}$ Health Sciences Library, University of Arizona,
1295 N Martin Avenue, Tucson, AZ 85721, USA. Division of Public Health Practice, Mel and Enid Zuckerman College of Public Health, 550 E. Van Buren Street, UA Phoenix Plaza Building 1, Phoenix, AZ 85006, USA.

Received: 28 August 2020 Accepted: 2 August 2021

Published online: 16 August 2021

\section{References}

1. United States Census Bureau. QuickFacts- Population estimates- Race and Hispanic Origin [Table]. 2018 Available from: https://www.census.gov/ quickfacts/fact/table/US/PST045218.

2. Cunningham TJ, Croft JB, Liu Y, Lu H, Eke PI, Giles WH. Vital signs: racial disparities in age-specific mortality among blacks or African Americans-United States, 1999-2015. MMWR Morb Mortal Wkly Rep. 2017; 66(17):444-56. https://doi.org/10.15585/mmwr.mm6617e1.

3. Hales CM, Carroll MD, Fryar CD, Ogden CL. Prevalence of obesity among adults and youth: United States, 2015-2016. NCHS data brief, no288. Hyattsville: National Center for Health Statistics; 2017.

4. Blackwell D, Lucas JW, Clarke T. Summary health statistics for U.S. adults: National Health Interview Survey, 2012. Atlanta: Census Bureau for the Centers for Disease Control and Prevention's National Center for Health Statistic; 2014.

5. Ward EM, Sherman RL, Henley SJ, Jemal A, Siegel DA, Feuer EJ, et al. Annual report to the nation on the status of Cancer, featuring Cancer in men and women age 20-49 years. J Natl Cancer Inst. 2019;111(12):1279-97.

6. Braveman P, Gottlieb L. The Social Determinants of Health: It's Time to Consider the Causes of the Causes. Public Health Rep. 2014;129(1_suppl2): 19-31.

7. Noonan AS, Velasco-Mondragon HE, Wagner FA. Improving the health of African Americans in the USA: an overdue opportunity for social justice. Public Health Rev. 2016;37(1):12. https://doi.org/10.1186/s40985-016-0025-4.

8. Boulware LE, Cooper LA, Ratner LE, LaVeist TA, Powe NR. Race and trust in the health care system. Public health reports; 2016.

9. Branson RD, Davis K Jr, Butler KL. African Americans' participation in clinical research: importance, barriers, and solutions. Am J Surg. 2007;193(1):32-9. https://doi.org/10.1016/j.amjsurg.2005.11.007.

10. Brown Speights JS, Nowakowski AC, De Leon J, Mitchell MM, Simpson I. Engaging African American women in research: an approach to eliminate health disparities in the African American community. Fam Pract. 2017;34(3): 322-9. https://doi.org/10.1093/fampra/cm×026.

11. Buchholz SW, Wilbur J, Schoeny ME, Fogg L, Ingram DM, Miller A, et al. Retention of African American women in a lifestyle physical activity program. West J Nurs Res. 2016;38(3):369-85. https://doi.org/10.1177/019394 5915609902.

12. Whitt-Glover MC, Borden SL, Alexander DS, Kennedy BM, Goldmon MV. Recruiting African American churches to participate in research: the learning and developing individual exercise skills for a better life study. Health Promot Pract. 2016:17(2):297-306. https://doi.org/10.1177/1524839915623499.

13. Lancaster KJ, Carter-Edwards L, Grilo S, Shen C, Schoenthaler AM. Obesity interventions in African American faith-based organizations: a systematic review. Obes Rev. 2014;15(Suppl 4):159-76. https://doi.org/10.1111/obr.12207.

14. Kim KH-C, Linnan L, Kramish Campbell M, Brooks C, Koenig HG, Wiesen C. The WORD (wholeness, oneness, righteousness, deliverance): a faith-based weight-loss program utilizing a community-based participatory research approach. Health Educ Behav. 2008;35(5):634-50. https://doi.org/10.1177/1 090198106291985

15. Kumanyika S, Taylor WC, Grier SA, Lassiter V, Lancaster KJ, Morssink CB, et al. Community energy balance: a framework for contextualizing cultural influences on high risk of obesity in ethnic minority populations. Prev Med. 2012;55(5):371-81. https://doi.org/10.1016/j.ypmed.2012.07.002.

16. Grant CG, Davis JL, Rivers BM, Rivera-Colón V, Ramos R, Antolino P, et al. The men's health forum: an initiative to address health disparities in the community. J Community Health. 2012;37(4):773-80. https://doi.org/10.1 007/s10900-011-9510-3.

17. Markens S, Fox SA, Taub B, Gilbert ML. Role of black churches in health promotion programs: lessons from the Los Angeles mammography promotion in churches program. Am J Public Health. 2002;92(5):805-10. https://doi.org/10.2105/AJPH.92.5.805.

18. Linnan L, Thomas S, D'Angelo H, Ferguson YO. African American barbershops and beauty salons, Community Organizing and Community Building for Health and Welfare, vol. 229; 2012. 
19. Linnan LA, D'Angelo $H$, Harrington CB. A literature synthesis of health promotion research in salons and barbershops. Am J Prev Med. 2014;47(1): 77-85. https://doi.org/10.1016/j.amepre.2014.02.007.

20. Johnson LT, Ralston PA, Jones E. Beauty salon health intervention increases fruit and vegetable consumption in African-American women. J Am Diet Assoc. 2010;110(6):941-5. https://doi.org/10.1016/j.jada.2010.03.012.

21. Hess PL, Reingold JS, Jones J, Fellman MA, Knowles P, Ravenell JE, et al. Barbershops as hypertension detection, referral, and follow-up centers for black men. Hypertension. 2007;49(5):1040-6. https://doi.org/10.1161/ HYPERTENSIONAHA.106.080432

22. Davis C, Darby K, Moore M, Cadet T, Brown G. Breast care screening for underserved African American women: community-based participatory approach. J Psychosoc Oncol. 2017;35(1):90-105. https://doi.org/10.1080/ 07347332.2016.1217965.

23. Floyd TD, DuHamel KN, Rao J, Shuk E, Jandorf L. Acceptability of a salonbased intervention to promote colonoscopy screening among African American women. Health Educ Behav. 2017;44(5):791-804. https://doi.org/1 $0.1177 / 1090198117726571$

24. Forte DA. Community-based breast cancer intervention program for older African American women in beauty salons. Public Health Rep (Washington, DC : 1974). 1995;110(2):179-83.

25. Luque J, Roy S, Tarasenko Y, Ross L, Johnson J, Gwede C, et al. Feasibility study of engaging barbershops for prostate Cancer education in rural African-American communities. J Cancer Educ. 2015;30(4):623-8. https://doi. org/10.1007/s13187-014-0739-2.

26. Luque J, Ross L, Gwede C. Qualitative systematic review of barberadministered health education, promotion, screening and outreach programs in African-American communities. J Community Health. 2014; 39(1):181-90. https://doi.org/10.1007/s10900-013-9744-3.

27. Wilson TE, Fraser-White M, Feldman J, Homel P, Wright S, King G, et al. Hair salon stylists as breast cancer prevention lay health advisors for African American and afro-Caribbean women. J Health Care Poor Underserved. 2008;19(1):216-26. https://doi.org/10.1353/hpu.2008.0017.

28. Sadler GR, Ko CM, Cohn JA, White M, Weldon RN, Wu P. Breast cancer knowledge, attitudes, and screening behaviors among African American women: the black cosmetologists promoting health program. BMC Public Health. 2007;7(1):57-8. https://doi.org/10.1186/14 71-2458-7-57.

29. Sadler GR, Ko CM, Wu P, Alisangco J, Castañeda SF, Kelly C. A cluster randomized controlled trial to increase breast cancer screening among African American women: the black cosmetologists promoting health program. J Natl Med Assoc. 2011;103(8):735-45. https://doi.org/10.1016/S002 7-9684(15)30413-2

30. Sadler GR, Ko CM, Wu P, Ngai P. Lessons learned from the black cosmetologists promoting health program: a randomized controlled tria testing a diabetes education program. J Commun Healthcare. 2014;7(2): 117-27. https://doi.org/10.1179/1753807614Y.0000000050.

31. Sadler GR, Thomas AG, Dhanjal SK, Gebrekristos B, Wright FA. Breast cancer screening adherence in African-American women: black cosmetologists promoting health. Cancer Interdisciplinary Int J Am Cancer Society. 1998; 83(S8):1836-9. https://doi.org/10.1002/(SICI)1097-0142(19981015)83:8+<183 6::AID-CNCR34>3.0.CO;2-E.

32. Sadler GR, Thomas AG, Gebrekristos B, Dhanjal SK, Mugo J. Black cosmetologists promoting health program: pilot study outcomes. J Cancer Educ. 2000;15(1):33-7. https://doi.org/10.1080/08858190009528650.

33. Browne RC. Most black women have a regular source of hair care--but not medical care. J Natl Med Assoc. 2006;98(10):1652-3.

34. Versey HS. Centering perspectives on black women, hair politics, and physical activity. Am J Public Health. 2014;104(5):810-5. https://doi.org/10.21 05/AJPH.2013.301675.

35. Smalls BL, Walker RJ, Bonilha HS, Campbell JA, Egede LE. Community interventions to improve glycemic control in African Americans with type 2 diabetes: a systemic review. Glob J Health Sci. 2015;7(5):171-82. https://doi. org/10.5539/gjhs.v7n5p171.

36. Fitzgibbon ML, Tussing-Humphreys LM, Porter JS, Martin IK, Odoms-Young A, Sharp LK. Weight loss and African-American women: a systematic review of the behavioural weight loss intervention literature. Obes Rev. 2012;13(3): 193-213. https://doi.org/10.1111/j.1467-789X.2011.00945.x.

37. Bland V, Sharma M. Physical activity interventions in African American women: a systematic review. Health Promotion Perspect. 2017;7(2):52-9. https://doi.org/10.15171/hpp.2017.11.
38. Barr-Anderson DJ, Adams-Wynn AW, DiSantis Kl, Kumanyika S. Familyfocused physical activity, diet and obesity interventions in African-American girls: a systematic review. Obes Rev. 2013;14(1):29-51. https://doi.org/1 0.1111/j.1467-789X.2012.01043.x.

39. Lofton S, Julion WA, McNaughton DB, Bergren MD, Keim KS. A systematic review of literature on culturally adapted obesity prevention interventions for African American youth. J Sch Nurs. 2016;32(1):32-46. https://doi.org/1 $0.1177 / 1059840515605508$.

40. UyBico SJ, Pavel S, Gross CP. Recruiting vulnerable populations into research: a systematic review of recruitment interventions. J Gen Intern Med. 2007;22(6):852-63. https://doi.org/10.1007/s11606-007-0126-3.

41. Ndumele CD, Ableman G, Russell BE, Gurrola E, Hicks LS. Publication of recruitment methods in focus group research of minority populations with chronic disease: a systematic review. J Health Care Poor Underserved. 2011; 22(1):5-23. https://doi.org/10.1353/hpu.2011.0031.

42. Moher D, Liberati A, Tetzlaff J, Altman DG. Preferred reporting items for systematic reviews and meta-analyses: the PRISMA statement. PLoS Med. 2009;6(7):e1000097. https://doi.org/10.1371/journal.pmed.1000097.

43. Palmer K, Rivers P, Melton F, McClelland J, Hatcher J, Marrero DG, et al. Protocol for a systematic review of health promotion interventions for African Americans delivered in US barbershops and hair salons. BMJ Open. 2020;10(4):e035940. https://doi.org/10.1136/ bmjopen-2019-035940.

44. Victor RG, Lynch K, Li N, Blyler C, Muhammad E, Handler J, et al. A clusterrandomized trial of blood-pressure reduction in black barbershops. $\mathrm{N}$ Engl J Med. 2018:378(14):1291-301. https://doi.org/10.1056/NEJMoa1717250.

45. Victor RG, Blyler CA, Li N, Lynch K, Moy NB, Rashid M, et al. Sustainability of blood pressure reduction in black barbershops. Circulation. 2019;139(1):10-9. https://doi.org/10.1161/CIRCULATIONAHA.118.038165.

46. Harris PA, Taylor R, Thielke R, Payne J, Gonzalez N, Conde JG. Research electronic data capture (REDCap)--a metadata-driven methodology and workflow process for providing translational research informatics support. J Biomed Inform. 2009;42(2):377-81. https://doi.org/10.1016/j.jbi.2008.08.010.

47. Armijo-Olivo S, Stiles CR, Hagen NA, Biondo PD, Cummings GG. Assessment of study quality for systematic reviews: a comparison of the Cochrane collaboration risk of Bias tool and the effective public health practice project quality assessment tool: methodological research. J Eval Clin Pract. 2012;18(1):12-8. https://doi.org/10.1111/j.1365-2753.2010.01516.x.

48. Jackson N, Waters E. Criteria for the systematic review of health promotion and public health interventions. Health Promot Int. 2005;20(4):367-74. https://doi.org/10.1093/heapro/dai022.

49. Victor RG, Ravenell JE, Freeman A, Leonard D, Bhat DG, Shafiq M, et al. Effectiveness of a barber-based intervention for improving hypertension control in black men: the BARBER-1 study: a cluster randomized trial. Arch Intern Med. 2011;171(4):342-50. https://doi.org/10.1001/archinternmed.201 0.390 .

50. Frencher SK Jr, Sharma AK, Teklehaimanot S, Wadzani D, Ike IE, Hart A, et al. PEP talk: prostate education program, "cutting through the uncertainty of prostate Cancer for black men using decision support instruments in barbershops". J Cancer Educ. 2016;31(3):506-13. https://doi.org/10.1007/s131 87-015-0871-7.

51. Holt CL. Cancer awareness in alternative settings: lessons learned and evaluation of the barbershop Men's health project. J Health Disparities Res Pract. 2010;4(2):100-10.

52. Odedina F, Oluwayemisi AO, Pressey S, Gaddy S, Egensteiner E, Ojewale EO, et al. Development and assessment of an evidence-based prostate cancer intervention programme for black men: the W.O.R.D. on prostate cancer video. Ecancermedicalscience. 2014;8(447-473):1-15.

53. Luque JS, Rivers BM, Gwede CK, Kambon M, Green BL, Meade CD. Barbershop communications on prostate cancer screening using barber health advisers. Am J Mens Health. 2011;5(2):129-39. https://doi.org/10.11 77/1557988310365167.

54. Chatterjee R, Slentz C, Davenport CA, Johnson J, Lin PH, Muehlbauer M, et al. Effects of potassium supplements on glucose metabolism in African Americans with prediabetes: a pilot trial. Am J Clin Nutr. 2017;106(6):1431-8. https://doi.org/10.3945/ajcn.117.161570.

55. Cole H, Thompson HS, White M, Browne R, Chau T-S, Braithwaite S, et al. Community-based, preclinical patient navigation for colorectal Cancer screening among older black men recruited from barbershops: the MISTER B trial. Am J Public Health. 2017;107(9):1433-40. https://doi.org/10.2105/A JPH.2017.303885. 
56. Victor RG, Ravenell JE, Freeman A, Leonard D, Bhat DG, Shafiq M, et al. Effectiveness of a barber-based intervention for improving hypertension control in black men. Arch Intern Med. 2011;171(4):342-50. https://doi.org/1 0.1001/archinternmed.2010.390.

57. Shavers-Hornaday VL, Lynch CF, Burmeister LF, Torner JC. Why are African Americans under-represented in medical research studies? Impediments to participation. Ethn Health. 1997;2(1-2):31-45. https://doi.org/10.1080/13 557858.1997.9961813.

58. Hughes TB, Varma VR, Pettigrew C, Albert MS. African Americans and clinical research: evidence concerning barriers and facilitators to participation and recruitment recommendations. The Gerontologist. 2017;57(2):348-58. https://doi.org/10.1093/geront/gnv118.

59. Graham LF, Scott L, Lopeyok E, Douglas H, Gubrium A, Buchanan D. Outreach strategies to recruit low-income African American men to participate in health promotion programs and research: lessons from the men of color health awareness (MOCHA) project. Am J Mens Health. 2018; 12(5):1307-16. https://doi.org/10.1177/1557988318768602.

60. Tucker CM, Wippold GM, Williams JL, Arthur TM, Desmond FF, Robinson KC. A CBPR study to test the impact of a church-based health empowerment program on health behaviors and health outcomes of black adult churchgoers. J Racial Ethn Health Disparities. 2017;4(1):70-8. https://doi. org/10.1007/s40615-015-0203-y.

61. Linnan $L A$, Ferguson $Y O$. Beauty salons: a promising health promotion setting for reaching and promoting health among African American women. Health Educ Behav. 2007;34(3):517-30. https://doi.org/10.1177/1 090198106295531

\section{Publisher's Note}

Springer Nature remains neutral with regard to jurisdictional claims in published maps and institutional affiliations.

Ready to submit your research? Choose BMC and benefit from:

- fast, convenient online submission

- thorough peer review by experienced researchers in your field

- rapid publication on acceptance

- support for research data, including large and complex data types

- gold Open Access which fosters wider collaboration and increased citations

- maximum visibility for your research: over $100 \mathrm{M}$ website views per year

At $\mathrm{BMC}$, research is always in progress.

Learn more biomedcentral.com/submissions 